\title{
The Mediterranean Diet Slows Down the Progression of Aging and Helps to Prevent the Onset of Frailty: A Narrative Review
}

\author{
Cristiano Capurso*(D), Francesco Bellanti ${ }^{\circledR}$, Aurelio Lo Buglio ${ }^{(}$and Gianluigi Vendemiale \\ Department of Medical and Surgical Sciences, University of Foggia, Viale Pinto 1, 71122 Foggia, Italy; \\ francesco.bellanti@unifg.it (F.B.); aurelio.lobuglio@unifg.it (A.L.B.); gianluigi.vendemiale@unifg.it (G.V.) \\ * Correspondence: cristiano.capurso@unifg.it
}

Received: 13 November 2019; Accepted: 18 December 2019; Published: 21 December 2019

\begin{abstract}
The aging population is rapidly increasing all over the world. This results in significant implications for the planning and provision of health and social care. Aging is physiologically characterized by a decrease in lean mass, bone mineral density and, to a lesser extent, fat mass. The onset of sarcopenia leads to weakness and a further decrease in physical activity. An insufficient protein intake, which we often observe in patients of advanced age, certainly accelerates the progression of sarcopenia. In addition, many other factors (e.g., insulin resistance, impaired protein digestion and absorption of amino acids) reduce the stimulation of muscle protein synthesis in the elderly, even if the protein intake is adequate. Inadequate intake of foods can also cause micronutrient deficiencies that contribute to the development of frailty. We know that a healthy eating style in middle age predisposes to so-called "healthy and successful" aging, which is the condition of the absence of serious chronic diseases or of an important decline in cognitive or physical functions, or mental health. The Mediterranean diet is recognized to be a "healthy food" dietary pattern; high adherence to this dietary pattern is associated with a lower incidence of chronic diseases and lower physical impairment in old age. The aim of our review was to analyze observational studies (cohort and case-control studies) that investigated the effects of following a healthy diet, and especially the effect of adherence to a Mediterranean diet (MD), on the progression of aging and on onset of frailty.
\end{abstract}

Keywords: Mediterranean diet; aging; frailty; sarcopenia

\section{Introduction}

Population aging is now a global phenomenon that is rapidly evolving all over the world. In the European Union, the number of people over sixty-five is expected to increase from 85 million in 2008 to 151 million in 2060 [1]. Worldwide, people aged over 65 are estimated to increase from 461 million in 2004 to 2 billion by 2050 [2,3]. This will have important consequences for the planning and delivery of health care and social assistance services. A greater life expectancy, in fact, leads us to reconsider not only the condition of the elderly, but also what kind of implications aging will have in our lifetime $[4,5]$. That is, the ability to dedicate ourselves to our activities will be no different from that of a younger person, wherever we spend our old age in good health. On the contrary, where the years of old age are dominated by loss of health, cognitive decline and therefore, the loss of self-sufficiency, the implications for individuals and for society as a whole would be much more negative [5]. Especially in high-income countries, it is now customary for many people to spend their old age in innovative ways, such as starting a new career or even starting new studies, or devoting oneself completely to a neglected passion during working age [6]. It is clear, however, that the extent of these new opportunities arising from these long years of life depends, for everyone, on maintaining health and self-sufficiency. 
Healthy behaviors in middle age predispose to so-called "healthy and successful" aging, which is the condition of the absence of serious chronic diseases or of important decline in cognitive or physical functions, or mental health [7]. Healthy behaviors include following a healthy diet, with an adequate caloric restriction to the state of health and physical activity, not smoking, intake of moderate amounts of alcohol, especially in women. Akbaraly et al. [8], and Samieri et al. [9] from the results of the Whitehall II cohort study and of the Nurses' Health Study, respectively, showed that a healthy dietary pattern, like the Mediterranean Diet (MD) pattern, was associated to a lower incidence of chronic disease and to a lower physical impairment in old age. In addition, they showed that a healthy dietary pattern was associated to a lower cardiovascular risk and to a lower risk of premature death.

The aim of our narrative review was to analyze observational studies (cohort and case-control studies) that investigated the effects of following a healthy diet, and especially the effect of adherence to MD, on the progression of aging and on the onset of frailty.

\section{Aging and Frailty}

The frailty of the elderly is a condition characterized by an increased vulnerability to poor homeostasis resolution after a stress event, which increases the risk of negative outcomes, including falls, delirium and disability. Most geriatricians intuitively recognize frailty; otherwise, this is mostly misunderstood, or confused with the presence of comorbidity and disability [10-12]. With the aim to provide a standardized definition for frailty, Fried et al. [13] identified the "frailty phenotype", which is the measure most frequently used. Fried's criteria of frailty considers five items to determine the level of frailty: weight loss, exhaustion, low physical activity, slowness, and weakness (Figure 1). Rockwood et al. [14] starting from the identification, through the Canadian Study on Health and Aging (CSHA), of 70 items including signs, symptoms and abnormal tests that characterized the fragility, built their "CSHA Clinical Frailty Scale", which considered seven levels, form Very fit to Severely frail (Figure 2). More correctly, frailty develops due to the greater decline, already linked to age, up to the severe impairment and the appearance of pathological states, of the different organs and systems, which overall, leads to a condition of greater vulnerability and reduced resilience and ultimately, to sudden and severe health changes triggered by even mild stressors. In the frail elderly an apparently small insult, for example, a small infection or minor surgery produces a significant worsening of the patient's condition. This means that the frail elderly loses all self-sufficiency, undergoes a hypokinetic syndrome to the condition of entrapment, increases the risk of falls, and develops a state of confusion, with a serious deterioration of cognitive functions. [15]. Frail people have several functional deficits, which often cause falls, immobility and confusion. They are the patients who come to the hospital with greater frequency and are the main recipients of long-term care services. [16]. About $25-50 \%$ of people over the age of 85 are estimated to have different degrees of frailty; these are subjects at high risk of falling, permanent disability and death, in most cases requiring long-term care [13,15]. However, if we consider that $25-50 \%$ of people over the age of 85 are frail, we must consider that that $50 \%$ to $75 \%$ of people over 85 years are not frail, which raises several questions, namely: How does frailty develop? How we can prevent it? How can we reliably detect it?

Frailty must not be understood as an inevitable consequence of aging, but rather, must be understood as a geriatric syndrome [13,17-19]. It is therefore more appropriate to speak of "frailty syndrome", i.e., a chronic pathological condition that results from the interaction of various factors, including aging-related physiological alterations, poly-pathology, nutritional deficiencies up to severe malnutrition, and the negative impact of socio-environmental factors (Figure 3). 


\begin{tabular}{|c|c|}
\hline \multicolumn{2}{|c|}{ Characteristics of Frailty } \\
\hline - Unintentional weight loss & $\begin{array}{l}\text { Baseline: }>4,5 \mathrm{Kg}(10 \mathrm{lbs}) \text { lost } \\
\text { unintentionally in prior year }\end{array}$ \\
\hline - Weakness & $\begin{array}{l}\text { Hand Grip: }<5,85 \mathrm{Kg}(12,89 \mathrm{lbs}) \text { for } \\
\text { males; }<3,37 \mathrm{Kg}(7,43 \mathrm{lbs}) \text { for females }\end{array}$ \\
\hline - Exhaustion & Self-reported: at least 3 days / week \\
\hline - Slowness & $\begin{array}{l}>7 \text { seconds to travel } 4.57 \mathrm{~m} \text { (15 feet) } \\
\text { on a known route }\end{array}$ \\
\hline - Low activity & $\begin{array}{l}\text { Assessed using the Physical Activity } \\
\text { Scale for the Elderly (PASE); or } \\
\text { Kcals/week: }<383 \text { Kcals/week for } \\
\text { males, }<270 \text { Kcals/week for females }\end{array}$ \\
\hline \multicolumn{2}{|c|}{ Presence of Frailty } \\
\hline \multicolumn{2}{|c|}{ Frailty phenotype: $\geq 3$ criteria present } \\
\hline
\end{tabular}

Figure 1. Fried's criteria of frailty (line 69).

\begin{tabular}{|l|}
\hline \multicolumn{1}{|c|}{ Very fit } \\
\hline $\begin{array}{l}\text { Robust, active, energetic, well motivated and fit; these people commonly } \\
\text { exercise regularly and are in the most fit group for their age }\end{array}$ \\
\hline \hline \multicolumn{1}{|c|}{ Well } \\
\hline Without active disease, but less fit than people in category 1 \\
\hline \multicolumn{1}{c|}{ Apparently vulnerable } \\
\hline Disease symptoms are well controlled compared with those in category 4 \\
\hline $\begin{array}{l}\text { Although not frankly dependent, these people commonly complain of being } \\
\text { "slowed up" or have disease symptoms }\end{array}$ \\
\hline \hline \multicolumn{1}{c|}{ Mildly frail } \\
\hline With limited dependence on others for instrumental activities of daily living \\
\hline \hline \multicolumn{1}{c|}{ Moderately frail } \\
\hline $\begin{array}{l}\text { Help is needed with both instrumental and non-instrumental activities of } \\
\text { daily living }\end{array}$ \\
\hline \hline \\
\hline $\begin{array}{l}\text { Completely dependent on others for the activities of daily living, or terminally } \\
\text { ill }\end{array}$ \\
\hline
\end{tabular}

Figure 2. The Canadian Study of Health and Aging (CSHA) Clinical Frailty Scale by Rockwood.

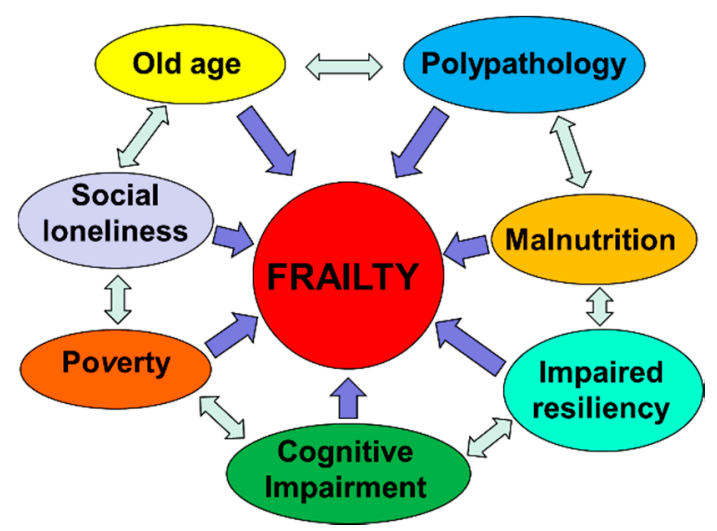

Figure 3. The vicious circle of frailty (line 92). 


\section{Aging, or Cellular Senescence, and Health}

If we consider aging solely from the biological point of view, we refer essentially to the physiological and progressive accumulation of senescent cells in tissues and organs, which occurs during the life of each individual [19], with the progressive slowing down and, in some cases, loss of function. The antagonist pleiotropic genes are a set of genes that regulate cellular senescence [20-23]; these genes play an important role in the prevention of malignant cell degeneration in the pre-neoplastic degeneration, i.e., eliminating cells from the cell cycle; the same genes are also involved in the mechanisms of protection in the physiological cellular senescence processes and towards age-related diseases [24-26].

The reduction of the capacity of cell regeneration and tissue repair are the basis of the physiological senescence process, substantially due to the slowdown process, up to the complete stop of the cycle of growth and replication of the progenitor cells. These aging cells also produce a series of proinflammatory and lytic molecules of the extracellular matrix in the process known as the secretory phenotype associated to senescence (SASP). Consequently, those mechanisms normally needed to maintain tissue homeostasis in the aging organism produce a series of alterations in the structure and function of the cells, resulting in degeneration and pathological senescence. The aging process also involves the immune system; in particular, the cell-mediated defense mechanism is slowed down. Furthermore, senescent cells do not produce enough signals to activate immune cells. As a result, a few aging senescent cells survive in the body. The senescent cells, in addition to reducing the functional efficiency of the organs and systems during aging, make them more vulnerable, therefore subject to further deterioration, after exposure to environmental stress factors [27].

In physiological aging, senescence is induced by the accumulation of different degenerative factors that slowly accumulate in the cells and that are responsible for macromolecular damage [28-30], for example, the shortening of telomeres, the addition of secondary DNA alterations to oxidative damage, stress degeneration of the endoplasmic reticulum (ER). The disease takes place when environmental stressors attack the tissues already in the presence of senescent cells with very low resilience capacities [31-33]. The stress that can cause the disease can be foreign and abnormal to the cell, as damaging DNA agents in cigarette smoke; otherwise, it can be a more intense response to a stressor event prolonged over time by the same factors that work in physiological aging, e.g., erosion of telomeres in lung epithelial cells chronically damaged by smoke [34]. It is therefore evident that aging is the result of a multi-factorial interaction between local and systemic environmental factors, and involutional factors due to cell senescence. Over time, these environmental stressors add to the cellular changes linked to physiological aging, decreasing resistance to stress and further reducing tissue resilience. That is, the chronic stimulation of a stressor factor on a tissue already in a condition of cellular senescence is more likely to induce the onset of a pathological condition [27].

\section{The Role of Senescence in the Progression of Diabetes Mellitus and Atherosclerosis}

Under physiological conditions, the synthesis and release of insulin by pancreatic beta cells, based on glycemic levels, allows the absorption of glucose in sensitive peripheral tissues, i.e., the liver and skeletal muscle, with the consequent production of energy by means of aerobic glycolysis [35]. In obese people, build-up of abdominal fat tissue, which is characterized by a chronic inflammatory state, and the excess of free circulating fatty acids, can cause a state of peripheral tissue insulin resistance [36,37]. Thus, what occurs is a condition of increased and abnormal prolonged demand in the time of production and release of insulin with the consequent prolonged stimulation of pancreatic beta cells. The increased replication activity, and consequently, the wear of telomeres, leads to premature senescence of beta cells [38], thus reducing the efficacy of the reaction to hyperglycaemia with the consequent aggravation of type 2 diabetes mellitus (T2DM) and the onset of insulin resistance. This reduced ability to regulate blood glucose levels alters the metabolic processes of the cells and speeds up the aging process. This glucose-induced cellular toxicity induces a condition of chronic stress and consequently, pathological senescence in various cell lines, for example, fibroblasts, cells of the renal tubules, endothelial cells, mesenchymal cells [39-42], and even neurons. Therefore, we see the 
appearance and progression of a number of diseases, such as atherosclerosis, chronic renal failure [43] and Alzheimer's disease. Furthermore, the accumulation of abdominal adipose tissue and the release in circulation of excess free fatty acids can also cause the progression of atherosclerosis. During the formation and progression of plaque, the proliferation of smooth muscles and the reduction of endothelial nitric oxide synthase levels can lead to the shortening of telomeres and increased oxidative stress, respectively [44,45]. Plaque progression is therefore the result of a series of interactions between smooth muscle cells and immune system cells, modulated by the synthesis and release of cytokines and adhesion molecules by endothelial cells, smooth muscle cells and immune cells. The complexity of the action mechanisms of senescent cells in the atherogenesis process is evident. Paradoxically, senescence in atherosclerosis acts as an initial protective factor by restricting and slowing the development of plaques and minimizing plaque-disrupting apoptosis. After a limit threshold of senescence burden, the proinflammatory matrix-degrading SASP exacerbates disease [27].

\section{Caloric Restriction, Effects on Metabolism of Adipose Tissue and Increase of Longevity}

It is known that overweight at young and middle age, by decreasing insulin sensitivity, can accelerate the aging process and predispose to the onset of age-related diseases [45-48]. In experimental models conducted both in mice and in humans, it has been observed that caloric restriction (CR) produces significant effects in terms of weight reduction; much of the weight loss comes from the reduction of white adipose tissue (WAT) and visceral fat deposits $[45,49,50]$. It is true that the common strains of laboratory rodents all have an extended lifespan in response to CR, however, this is not a universal effect. Interestingly, some inbred mice strains show only a modest effect on extension of the life span after CR. In some cases, a reduction in life span has even been observed [51]. We can explain these apparently conflicting results considering that the effect of CR on the metabolism is a decrease in carbohydrate dependence and a greater use of fatty acid oxidation to produce energy [52]. Indeed, the level of fat reduction following dietary restriction remains a key component of the beneficial effects of CR. In a study conducted on 40 strains of mice, increased longevity induced by CR was more evident in old mice (15-17 months of age) that, with a $40 \%$ CR diet, were able to retain more fat deposits, showing that retainment of both fat mass and lean mass in aging can correlate with more longevity [53]. Subsequently, the results of a study conducted on progeroid mice showed that a caloric restriction regimen of $30 \%$ increased its median duration and the maximum residual life expectancy by three times. Specifically, mice subjected to caloric restriction retained 50\% more neurons and maintained full motor function, far beyond the lifespan of ad libitum-fed mice.

\section{Caloric Restriction and Inflammatory State}

Gene expression analysis has shown that dietary restriction increases DNA resistance to stress-induced damage, as well as improving antioxidant defenses and metabolic processes primarily mediated by insulin, as well as by other hormonal signaling pathways. Dietary restriction also affects mitochondria activity, modulates apoptotic response and modifies pro-inflammatory and anti-inflammatory cytokine production [54]. The results of further randomized human studies confirm that caloric restriction stimulates the body to adapt to the use of any available energy substrate, both glucose and fatty acids [55]. The term "metabolic flexibility" optimally defines this adaptation property, which has long been linked to metabolic health and longevity [56]. Studies conducted on primates have also shown that a strong relationship exists between $\mathrm{CR}$ and the reduction of the pro-inflammatory state [57]. A subsequent study linked the reduction of the pro-inflammatory state to the inhibition of the inflammasome, induced, in turn, by the increase in serum levels of $\beta$-hydroxybutyrate during fasting [58]. Another suggested a mechanism through which CR could suppress the harmful activation of the immune system, which concerns the preservation of the thyme function induced by the CR, thus preserving the function of T cells [59], or a reduction of inflammation induced by oxidative stress [60]. 


\section{Caloric Restriction, Mitochondria Activity and Reactive Oxygen Species Production}

Numerous experimental models conducted on animal organisms have involved mitochondrial proteins encoded by the nucleus in the life span adjustment process [61,62]. These experiments on genes mostly involved an alteration of the electron transport chain process with consequent impairment of mitochondrial function; nevertheless, they have led to a greater life expectancy [48]. Conversely, in mice models bearing significant mitochondrial genome mutations designed to significantly impair mitochondrial function, a phenotype characterized by accelerated aging was observed $[63,64]$. The seemingly contradictory results observed in these experimental models may be due to the variability of the alteration of mitochondrial function that was obtained from time to time. Experiments conducted on C. elegans have shown an increase in life expectancy as a result of a modest reduction of the various components of the mitochondrial electron transport, while a significant reduction, i.e., a sign of high mitochondrial damage, was associated with a reduction in the lifespan [65]. Evidence from mammalian models has shown that a slight reduction in mitochondrial function is associated with prolonging lifespan. This assumption seems to contradict the hypothesis that reactive oxygen species (ROS) support aging [66]. In fact, although mitochondrial ROS can be dangerous for life [67], it is equally clear that a slight stimulation of mitochondrial ROS production can stimulate the activation of the anti-redox mechanism with protective effects in the long term.

\section{Caloric Restriction, Hormesis and Mitochondria Activity during Aging}

"Hormesis", from the Greek verb "ormao" that means "to stimulate", is described as the adaptive function of a cell or an organism characterized by a biphasic dose-dependent response, following exposure to a variety of stimuli, such as toxins or other stressors. The hormetic responses, generally, show a modest stimulation of the response of the organism to low doses of a stressor, or an inhibition of the same response to high doses [68]. "Mitochesis" is defined as the hermetic response of the mitochondria, i.e., that the activation of a low level of stress can protect against major and subsequent stress [69-71]. It is therefore clear that ROS levels are not the only factor responsible for mitochondrial stress affecting life span. Another mechanism linking the aging of mitochondria is constituted by the turnover capacity, that is, the balance between biogenesis, or the synthesis of new mitochondria, and mitophagy, or the removal of aged and damaged mitochondria. It is now clear that all interventions, such as CR, which result in greater longevity, act by inducing mitochondrial biogenesis through the expression of peroxisome proliferation-activated receptor gamma (PPAR- $\gamma$ ), and coactivator 1 alpha (PGC-1 $\alpha$ ) [72,73]. It is equally clear that the reduction of biogenesis contributes to the onset of age-related diseases, both through the reduced activity of PGC-1 $\alpha$ and through other routes. [74]. A gradual reduction in autophagic activity associated with aging was also observed [75]; a similar age-related decline is also likely to affect the more specialized process of mitophagy. On the contrary, in experimental models, the increase in the expression of gene products that stimulate mitochondrial activity has been observed to determine a prolongation of life expectancy [76].

\section{Caloric Restriction and DNA Methylation}

In addition, DNA methylation (methylation drift) is an important epigenetic modification that involves the addition of a methyl group in the cytosine 5 position by DNA methyltransferase to form 5-methylcyctosine (5-mC). This epigenetic mark has the power to activate or deactivate genes and can be inherited through cell division. DNA methylation plays an important role in normal human development, aging, tumorigenesis and other genetic and epigenetic diseases $[48,77,78]$. Maegawa et al. [79] found that DNA methylation drifts with age in both mice and humans and monkeys. They also found that Methylation drift is inversely proportional to lifespan across these three-mammalian species. In their elegant study, authors also found that a sample of 22 to 30 -year-old rhesus monkeys exposed to 30\% CR since 7-14 years of age showed attenuation of age-related methylation drift compared to ad libitum-fed controls, such that their blood methylation age appeared 
7 years younger than their chronologic age. They observed the same and more pronounced effects in 2.7-3.2-year-old mice exposed to $40 \%$ CR starting at 0.3 years of age.

\section{Caloric Restriction, Metabolic Adaptation and Oxidative Damage}

Readman et al., in the CALERIE Study [80]., delivered a highly controlled and intensive behavioral trial targeting a $25 \%$ CR diet over 2 years in a sample of 53 voluntary and non-obese adults ( $34 \mathrm{CR}$ and 19 controls); then, they measured, in a room calorimeter, the component of daily sedentary energy expenditure, i.e., the energy metabolism during sleep. They also measured hormonal mediators of metabolism, including leptin and thyroid hormones, along with urinary F2-isoprostane excretion as an index of oxidative damage. After two years, subjects in the CR group experienced an average weight loss of $8.7 \mathrm{Kg}$, whereas subjects in the control group maintained weight during the 2-year period. In the $\mathrm{CR}$ group, the greater weight loss was from fat mass after two years $(-3.2 \mathrm{Kg} ; p>0.001)$. In addition, the authors found a significative reduction of 24-h Energy Expenditure ( $-186 \mathrm{Kcal} / \mathrm{day}$; $p<0.05)$, and a significative reduction in Sleep Energy Expenditure $(-160 \mathrm{Kcal} /$ day; $p<0.05)$ in the $\mathrm{CR}$ group after two years, indicating a metabolic adaptation to the CR. After adjustment for changes in body composition, while Sleep Energy Expenditure was significantly decreased in the CR group after two years $(p<0.05)$, the 24-h Energy Expenditure did not decrease significantly after two years, compared to the control group $(p>0.55)$. As regards the biomarkers of Energy Metabolism and aging, authors found a significant reduction in the CR group after two years of T3 $(-0.73 \mathrm{ng} / \mathrm{dl} ; p<0.05), \mathrm{T} 4$ $(-0.16 \mathrm{mcg} / \mathrm{dl} ; p<0.05)$, and leptin $(-9.3 \mathrm{ng} / \mathrm{dl} ; p<0.05)$; in addition, they observed a reduction of fasting insulin and of nigh time core body temperature. Regarding the markers of oxidative stress, the authors found a significative reduction of the urinary excretion of four F2-isoprostane isomers after two years in the CR group $(-0.49 \mathrm{ng} / \mathrm{mg} \mathrm{CR} ; p<0.05)$. The authors have linked these data to the metabolic adaptation of the 24-h Energy Expenditure after the CR. The author also linked the CR with an improved mitochondrial function, with a decreased total body oxygen consumption, and therefore, with a decreased reduction of Oxidative Stress.

\section{Mediterranean Diet, Cardiovascular Disease and Mortality}

The traditional Mediterranean Diet (MD) is characterized by a high intake of foods of plant origin (fruit, vegetables, breads, other cereals, potatoes, beans, nuts, and seeds) and fresh fruit. Olive oil, namely extra-virgin olive oil, is the main source of fat. Dairy products (mainly light cheeses and yogurt), fish and poultry are consumed in medium-low quantities; particularly, fish is an excellent source of polyunsaturated fatty acids (PUFAs), particularly omega-3 fatty acids; egg consumption is limited to a maximum of four per week; red meat is consumed sporadically and in small quantities, however, no more than once a week. MD has a very low saturated fat content, which represents no more than $8-10 \%$ of the total caloric intake. Caloric intake from lipids is not more than $30 \%$ of total caloric intake. Wine is usually consumed with meals, but always in moderate doses (1-2 glasses) [81,82]. Ancel Keys first demonstrated the health benefits derived from the MD [83]; thanks to early studies of Ancel Keys, MD has been proposed as a healthy dietary pattern associated with a lower risk of developing cardiovascular and metabolic diseases. The traditional MD has been proposed as a food model to achieve or maintain optimal weight. Trichopoulou et al. [84] showed that high adherence to the MD, assessed by the Mediterranean Diet Score (MDS), was related to a significative reduction of total mortality [85].

Subsequently, the PREDIMED study [86] confirmed the finding above. The authors have shown that all subjects at high cardiovascular risk who followed an MD pattern, supplemented with monounsaturated fatty acids and antioxidants, that is, extra-virgin olive oil (EVOO), or with omega-3 poly-unsaturated fatty acids, that is nuts, had a reduced Hazard Risk (HD) of acute myocardial infarction, stroke or death from any cardiovascular event (MD with EVOO: HR $=0.70,95 \%$ CI: $0.53-0.91$, $p=0.009$; MD with nuts: HR $=0.70,95 \%$ CI: $0.53-0.94, p=0.02$ ). They did not observe any effect on 
reduction of all-cause mortality (MD with EVOO: $\mathrm{HR}=0.81,95 \% \mathrm{CI}: 0.63-1.05, p=0.11$; $\mathrm{MD}$ with nuts: $\mathrm{HR}=0.95,95 \%$ CI: $0.73-1.23, p=0.68$ ).

The authors subsequently identified protocol deviations, including the enrolment of household members without randomization, assignment to a study group without randomization of some participants at one of 11 study sites, and apparent inconsistent use of randomization tables at another site. Then, they published a new revised report, which was based on analyses that do not rely exclusively on the assumption that all the participants were randomly assigned [87]. In their second report, the authors confirmed the lower risk of acute myocardial infarction, ischemic stroke, or death from all cardiovascular event among subjects who were assigned to an MD pattern respect to control subjects who were assigned to a low-fat diet.

A subsequent meta-analysis [88] analyzed the relationship between adherence to MD and mortality and incidence of each disease; 1,574,299 subjects were involved; they were followed for a time ranging from three to 18 years. The authors demonstrated a significant association between greater adherence to MD, a significant improvement in health status and a significant reduction in mortality Rate Risk $(\mathrm{RR})(\mathrm{RR}=0.91,95 \% \mathrm{CI}: 0.89-0.94 ; p<0.0001)$. The authors have also shown that a greater adherence to an MD pattern was associated with a significant reduction in mortality due to coronary heart disease (CHD) (RR $=0.91,95 \%$ CI: 0.87-0.95, $p<0.0001$ ) and to cancer (RR $=0.94 ; 95 \%$ CI: $0.92-0.96 ; p<0.0001)$.

A further meta-analysis conducted by the same authors [89] further showed that a great adherence to MD was associated with an improvement in health status and quality of life and to a significant reduction in overall mortality ( $R R=0.92,95 \%$ CI: $0.90-0.94, p<0.00001$ ). Specifically, authors showed a significative reduction of mortality from coronary heart disease ( $R \mathrm{R}=0.90 ; 95 \% \mathrm{CI}$ : $0.87-0.93$; $p<0.00001$ ) and from cancer ( $R R=0.94 ; 95 \%$ CI: 0.92-0.96; $p<0.00001)$. A high adherence to MD was also associated with a significant reduction in the incidence of neurodegenerative diseases $(R R=0.87$; 95\% CI: 0.81-0.94; $p<0.00001)$, including Alzheimer's disease.

Nevertheless, as already emphasized in an excellent editorial by Voelker [90], it would be simplistic to consider the MD as a simple semi-vegan diet rich in fibers, antioxidants and proteins of vegetable origin. We observe the benefits of the MD in its cultural context, where food is part of a lifestyle.

In 2011, the Mediterranean Diet Foundation together with the forum on Mediterranean food cultures developed a consensus document that revised the pyramid of the Mediterranean diet, including cultural and lifestyle elements [91]. The authors underlined the aspects of socialization, by writing, "The aspect of conviviality is important for the social and cultural value of the meal, beyond nutritional aspects. Cooking, sitting around the table and sharing food in company of family and friends is a social support and gives a sense of community. Make cooking an important activity taking the proper time and space. Cooking can be relaxing, fun and can be done with family, friends and the loved ones". At least 30 min of moderate exercise during the day "as a dietary supplement" and adequate rest at night and during the day in the form of a nap after a meal are also recommended in the consent document.

Lastly, Kromhout et al. [92], further confirmed how a food model according to the features of the $\mathrm{MD}$, assessed through the Mediterranean Adequacy Index, was inversely associated with mortality due to ischemic heart disease $(\mathrm{r}=-0.91)$. In particular, the authors confirmed the protective role of cereals $(r=-0.52)$, vegetables $(r=-0.52)$ and legumes $(r=-0.62)$, in addition to the intake of moderate amounts of alcohol in the diet $(\mathrm{r}=-0.54)$. The authors also confirmed the association between ischemic mortality of heart disease and dietary intake of high amounts of saturated fatty acids $(r=0.83)$, whole milk $(r=0.84)$, confectionery preparations based on simple sugars $(r=0.69)$, animal meats, with the exception of fish $(r=0.68)$, and preparations based on animal meats and simple sugars, for example, processed meats $(\mathrm{r}=0.84)$. Table 1 summarizes the studies we examined. 
Table 1. Mediterranean Diet adherence and risk of mortality.

\begin{tabular}{|c|c|c|c|}
\hline Author and Year of Publication & Study Design & Sample Size & Risk of Mortality \\
\hline Trichopoulou, 2003, [84] & Population-based, prospective study & 8895 men and 13,148 women & 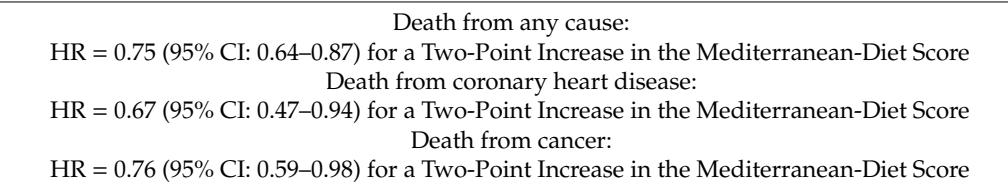 \\
\hline Estruch, 2013, [86] & $\begin{array}{c}\text { Parallel-group, multicentre, randomized } \\
\text { trial }\end{array}$ & $\begin{array}{c}1050 \text { men and } 1493 \text { women with MD } \\
\text { with EVOO } \\
1128 \text { men and } 1326 \text { women with MD } \\
\text { with nuts } \\
987 \text { men and } 1463 \text { women with Control } \\
\text { Diet }\end{array}$ & $\begin{aligned} \text { Myocardial infarction, stroke, and death from cardiovascular causes: } \\
\text { HR }=0.70 \text { (95\% CI: 0.54-0.92, } p=0.01) \text { for MD with EVOO vs. Control Diet } \\
\text { HR }=0.72 \text { (95\% CI: 0.54-0.96, } p=0.03) \text { for MD with Nuts vs. Control Diet } \\
\text { Death from any cause: } \\
\text { HR }=0.82 \text { (95\% CI: } 0.64-1.07, p=0.15) \text { for MD with EVOO vs. Control Diet } \\
\text { HR }=0.97 \text { (95\% CI: } 0.74-1.26, p=0.82) \text { for MD with Nuts vs. Control Diet }\end{aligned}$ \\
\hline Estruch, 2018, [87] & $\begin{array}{c}\text { Parallel-group, multicentre, randomized } \\
\text { trial }\end{array}$ & $\begin{array}{c}1050 \text { men and } 1493 \text { women with MD } \\
\text { with EVOO } \\
1128 \text { men and } 1326 \text { women with MD } \\
\text { with nuts } \\
987 \text { men and } 1463 \text { women with Control } \\
\text { Diet }\end{array}$ & $\begin{array}{c}\text { Myocardial infarction: } \\
\text { HR }=0.82(95 \% \text { CI: } 0.52-1.30) \text { for MD with EVOO vs. Control Diet } \\
\text { HR }=0.76(95 \% \text { CI: } 0.47-1.25) \text { for MD with Nuts vs. Control Diet } \\
\text { Stroke: } \\
\text { HR }=0.65(95 \% \text { CI: } 0.44-0.95) \text { for MD with EVOO vs. Control Diet } \\
\mathrm{HR}=0.54(95 \% \text { CI: } 0.35-0.82) \text { for MD with Nuts vs. Control Diet } \\
\text { Death from cardiovascular causes: } \\
\text { HR }=0.62(95 \% \text { CI: } 0.36-1.06) \text { for MD with EVOO vs. Control Diet } \\
\mathrm{HR}=1.02(95 \% \text { CI: } 0.63-1.67) \text { for MD with Nuts vs. Control Diet } \\
\text { Death from any cause: } \\
\text { HR }=0.90(95 \% \text { CI: } 0.69-1.18) \text { for MD with EVOO vs. Control Diet } \\
\mathrm{HR}=1.12(95 \% \text { CI: } 0.86-1.47) \text { for MD with Nuts vs. Control Diet }\end{array}$ \\
\hline Sofi, 2008, [88] & $\begin{array}{l}\text { Meta-analysis of prospective cohort } \\
\text { studies }\end{array}$ & $1,574,299$ subjects from 12 studies & $\begin{array}{c}\text { Mortality from cardiovascular diseases: } \\
\text { RR }=0.91 \text { ( } 95 \% \text { CI: } 0.87-0.95 \text { ) } \\
\text { Mortality from any cause: } \\
\text { RR }=0.91 \text { ( } 95 \% \text { CI: } 0.89-0.94 \\
\text { Mortality from cancer: } \\
\text { RR }=0.94 \text { ( } 95 \% \text { CI: } 0.92-0.96 \text { ) } \\
\text { Incidence of Parkinson's disease and Alzheimer's disease: } \\
\text { RR }=0.87 \text { ( } 95 \% \text { CI: } 0.80-0.96 \text { ) }\end{array}$ \\
\hline Sofi, 2010, [89] & $\begin{array}{l}\text { Meta-analysis of prospective cohort } \\
\text { studies }\end{array}$ & 508,393 subjects from 7 studies & $\begin{array}{l}\text { Mortality from cardiovascular diseases: } \\
\text { RR }=0.90 \text { ( } 95 \% \text { CI: } 0.87-0.93 \text { ) } \\
\text { Mortality from any cause: } \\
\text { RR }=0.92 \text { ( } 95 \% \text { CI: } 0.90-0.94) \\
\text { Mortality from cancer: } \\
\text { RR }=0.94 \text { ( } 95 \% \text { CI: } 0.92-0.96) \\
\text { Incidence of neurodegenerative disease: } \\
\text { RR }=0.87 \text { ( } 95 \% \text { CI: } 0.81-0.94)\end{array}$ \\
\hline Kromhout, 2018, [92] & Prospective Cohort Study & $\begin{array}{l}12,763 \text { subjects from } 16 \text { cohorts of the } \\
\text { Seven Countries Study }\end{array}$ & $\begin{array}{c}\text { Mortality from cardiovascular diseases: } \\
\text { Inverse association between consumption of cereals, vegetables, legumes, and alcohol and } \\
\text { long-term CHD mortality rates }(\mathrm{r}=-0.52 \text { to }-0.62) \\
\text { Positive association between consumption of hard fat plus sweet products, animal foods except } \\
\text { fish, and long-term CHD mortality rates ( }(\mathrm{r}=0.68 \text { to } 0.84)\end{array}$ \\
\hline
\end{tabular}




\section{Omega-3 Poly-Unsaturated Fatty Acids and Aging}

The three types of n-3 fatty acids involved in human physiology are $\alpha$-linolenic acid (ALA), which is found in plant oils, eicosapentaenoic acid (EPA), and docosahexaenoic acid (DHA), both commonly found in marine oils.

As summarized in Table 2, since 1999, the Gruppo Italiano per lo Studio della Sopravvivenza nell'Infarto Miocardico (GISSI)-Prevenzione trial, [93] an open-label trial involving 11,323 survivors of MI, reported that patients who received supplementation with omega-3 Fatty Acids (FAs) experienced a $10 \%$ reduced risk of major cardiovascular events compared with untreated controls.

The Japan EPA Lipid Intervention Study (JELIS) trial [94] is an open-label trial involving 18,645 participants with total cholesterol of $6.3 \mathrm{mmol} / \mathrm{L}(243.24 \mathrm{mg} / \mathrm{dL})$ or greater, of whom only $20 \%$ had prior CHD. Authors showed that among patients who were given EPA treatment, major coronary events were reduced by $19 \%$ (EPA group vs. controls: $\mathrm{HR}=0.81 ; 95 \% \mathrm{CI}: 0.69-0.95 ; p=0.011$ ). In patients with a history of coronary artery disease who were given EPA treatment, major coronary events were reduced by $19 \%$ (EPA group vs. controls: $\mathrm{HR}=0.81 ; 95 \%$ CI: $0.66-1.00 ; p=0.048$ ). In patients with no history of coronary artery disease, EPA treatment reduced major coronary events by $18 \%$, but this finding did not reach statistical significance (EPA group vs. controls: $0.82(0.63-1.06) \mathrm{HR}=0.82 ; 95 \%$ CI: $0.63-1.06 ; p=0.132$ ).

Seven large randomized trials [95-101] were conducted to compare the associations of treatment with omega-3 FAs supplementation vs. placebo or no treatment for at least 12 months in populations with prior CHD, stroke, or high risk of cardiovascular disease (CVD). These large trials all failed to demonstrate a significative reduction of the incidence of major cardiovascular events.

In addition, four meta-analyses involving large trials of omega-3 FA supplements [102-105] reported conflicting results demonstrating a significative reduction of overall mortality, of mortality due to myocardial infarction, and of sudden death in patients with coronary heart disease. 
Table 2. Poly-unsaturated fatty acids intake and mortality.

\begin{tabular}{|c|c|c|c|}
\hline Author and Year of Publication & Study Design & Sample Size & Risk of Mortality \\
\hline GISSI Prevention trial, 1999, [93] & Prospective Cohort Study & $\begin{array}{c}8496 \text { cases and } 2828 \text { controls from a cohort of } 11,324 \\
\text { subjects }\end{array}$ & $\begin{array}{c}\text { Death, non-fatal MI, and non-fatal stroke in two-way analysis: } \\
\text { RR }=0.90 \text { ( } 95 \% \text { CI: } 0.82-0.99, p=0.048) \\
\text { Cardiovascular death, non-fatal MI, and non-fatal stroke in two-way analysis: } \\
\text { RR }=0.89 \text { ( } 95 \% \text { CI: } 0.80-1.01, p=0.053) \\
\text { Death, non-fatal MI, and non-fatal stroke in four-way analysis: } \\
\text { RR }=0.85(95 \% \text { CI: } 0.74-0.98, p=0.023) \\
\text { Cardiovascular death, non-fatal MI and non-fatal stroke in four-way analysis: } \\
\text { RR }=0.80 \text { ( } 95 \% \text { CI: } 0.68-0.95, p=0.008)\end{array}$ \\
\hline Yokoyama, 2007, [94] & $\begin{array}{l}\text { Prospective Randomised Open-Label } \\
\text { Cohort Study }\end{array}$ & $\begin{array}{l}9326 \text { EPA treatments and } 9319 \text { controls from a cohort } \\
\text { of } 18,645 \text { subjects }\end{array}$ & $\begin{array}{l}\text { Incidence of coronary events in the total study population: } \\
\mathrm{HR}=0.81 \text { ( } 95 \% \text { CI: } 0.69-0.95, p=0.011) \text { for EPA treatments vs. controls; } \\
\text { Incidence of coronary events in in the primary prevention arm: } \\
\mathrm{HR}=0.82 \text { ( } 95 \% \text { CI: } 0.63-1.06, p=0.132 \text { ) for EPA treatments vs. controls; } \\
\text { Incidence of coronary events in in the secondary prevention arm: } \\
\text { HR }=0.81 \text { ( } 95 \% \text { CI: } 0.66-1.00, p=0.048) \text { for EPA treatments vs. controls }\end{array}$ \\
\hline Kromhout, 2010, [95] & $\begin{array}{l}\text { Prospective Multi-centre, double-blind } \\
\text { trial: } n-3 \text { fatty acids EPA and DHA and } \\
\text { plant-derived ALA vs. placebo }\end{array}$ & $\begin{array}{c}1212 \text { subjects randomized to receive EPA-DHA and } \\
\text { ALA; } \\
1192 \text { subjects randomized to receive EPA-DHA and } \\
\text { ALA placebo; } \\
1197 \text { subjects randomized to receive EPA-DHA } \\
\text { placebo and ALA; } \\
1236 \text { subjects randomized to receive EPA-DHA } \\
\text { placebo and } \\
\text { ALA placebo }\end{array}$ & $\begin{array}{c}\text { Major cardiovascular events: } \\
\text { HR }=1.01(95 \% \text { CI: } 0.87-1.17, p=0.93) \text { with EPA-DHA; } \\
\text { HR }=0.91(95 \% \text { CI: } 0.78-1.05, p=0.20) \text { with ALA }\end{array}$ \\
\hline Einvik, 2010, [96] & Interventional Clinical Trial & $\begin{array}{l}563 \text { Norwegian men randomized to a 3-year clinical } \\
\text { trial of diet with n-3 PUFA supplementation vs. } \\
\text { placebo (corn oil) }\end{array}$ & $\begin{array}{c}\text { Mortality from any cause: } \\
\text { HR }=0.57 \text { ( } 95 \% \text { CI: } 0.29-1.10) \\
\text { Mortality from cardiovascular diseases: } \\
\text { HR }=0.86 \text { ( } 95 \% \text { CI: } 0.57-1.38)\end{array}$ \\
\hline Bosch, 2012, [97] & $\begin{array}{l}\text { Prospective multi-centre, double-blind } \\
\text { trial: } n-3 \text { fatty acids vs. placebo }\end{array}$ & $\begin{array}{l}6281 \text { subjects randomized to receive } \mathrm{n}-3 \text { fatty acids; } \\
6255 \text { subjects randomized to receive placebo }\end{array}$ & $\begin{array}{c}\text { Death from cardiovascular causes: } \\
\text { HR }=0.98 \text { ( } 95 \% \text { CI: } 0.87-1.10, p=0.72) \\
\text { Myocardial Infarction, Stroke, or Cardiovascular Death: } \\
\text { HR }=1.01 \text { ( } 95 \% \text { CI: } 0.93-1.10, p=0.81) \\
\text { Death from Any Cause: } \\
\text { HR }=0.98(95 \% \text { CI: } 0.89-1.07, p=0.63) \\
\text { Death from Arrhythmia: } \\
\text { HR }=1.10 \text { ( }(95 \% \text { CI: } 0.93-1.30, p=0.26)\end{array}$ \\
\hline Rauch, 2010, [98] & $\begin{array}{l}\text { Prospective randomized, } \\
\text { placebo-controlled, double-blind, } \\
\text { multicentre trial }\end{array}$ & $\begin{array}{l}1919 \text { subjects randomized to receive } \mathrm{n}-3 \text { fatty acids; } \\
1885 \text { subjects randomized to receive placebo }\end{array}$ & $\begin{array}{c}\text { Sudden cardiac death: } \\
\text { OR }=0.95(95 \% \text { CI: } 0.56-1.60, p=0.84) \\
\text { Total mortality: } \\
\text { OR }=1.25 \text { (95\% CI: } 0.90-1.72, p=0.18) \\
\text { Major adverse cerebrovascular and cardiovascular } \\
\text { Events: } \\
\text { OR }=1.21(95 \% \text { CI: } 0.96-1.52, p=0.10) \\
\text { Revascularization in survivors: } \\
\text { OR }=0.93 \text { (95\% CI: } 0.80-1.08, p=0.34)\end{array}$ \\
\hline
\end{tabular}


Table 2. Cont.

\begin{tabular}{|c|c|c|c|}
\hline Author and Year of Publication & Study Design & Sample Size & Risk of Mortality \\
\hline Galan, 2010, [99] & $\begin{array}{l}\text { Prospective randomized, } \\
\text { placebo-controlled, double-blind trial }\end{array}$ & $\begin{array}{c}620 \text { subjects randomized to receive B vitamins + } \\
\text { omega } 3 \\
\text { fatty acids; } \\
633 \text { subjects randomized to receive Omega } 3 \text { fatty } \\
\text { acids; } \\
622 \text { subjects randomized to receive B vitamins; } \\
626 \text { subjects randomized to receive placebo }\end{array}$ & $\begin{array}{l}\text { Non-fatal myocardial infarction, stroke, or death from cardiovascular disease: } \\
\qquad \begin{array}{c}\text { HR }=1.08 \text { ( } 95 \% \text { CI: } 0.79-1.47, p=0.64) ; \\
\text { Total mortality: } \\
H R=1.03(95 \% \text { CI: } 0.72-1.48, p=0.88)\end{array}\end{array}$ \\
\hline Bonds, 2014, [100] & $\begin{array}{l}2 \times 2 \text { factorial-designed randomized } \\
\text { clinical trial }\end{array}$ & $\begin{array}{c}1079 \text { subjects randomized to receive lutein + } \\
\text { zeaxanthin and DHA + EPA; } \\
1068 \text { subjects randomized to receive DHA + EPA; } \\
1044 \text { subjects randomized to receive lutein + } \\
\text { zeaxanthin; } \\
1012 \text { subjects randomized to receive placebo } \\
\end{array}$ & $\begin{array}{c}\text { Time to First Cardiovascular Disease Mortality/Morbidity Event: } \\
\text { HR = 0.95 (95\% CI: 0.78-1.17) for DHA + EPA vs. No DHA + EPA; } \\
\text { HR = } 0.94(95 \% \text { CI: } 0.77-1.15) \text { for Lutein + zeaxanthin vs. No Lutein + zeaxanthin }\end{array}$ \\
\hline Deepak, 2019, [101] & $\begin{array}{l}\text { Multicentre, randomized, double-blind, } \\
\text { placebo-controlled trial }\end{array}$ & $\begin{array}{c}4089 \text { subjects randomized to receive } 2 \mathrm{~g} \text { of Icosapent } \\
\text { Ethyl twice daily; } \\
4090 \text { subjects randomized to receive placebo }\end{array}$ & $\begin{array}{l}\text { Cardiovascular death, nonfatal myocardial infarction, nonfatal } \\
\text { stroke, coronary revascularization, or unstable angina: } \\
\text { HR }=0.75(95 \% \text { CI: } 0.68-0.83, p<0.001)\end{array}$ \\
\hline Bucher, 2002, [102] & $\begin{array}{l}\text { Meta-analysis from } 11 \text { case-control } \\
\text { studies }\end{array}$ & $\begin{array}{l}7951 \text { patients in the treatment groups and } 7855 \\
\text { patients in the control groups }\end{array}$ & 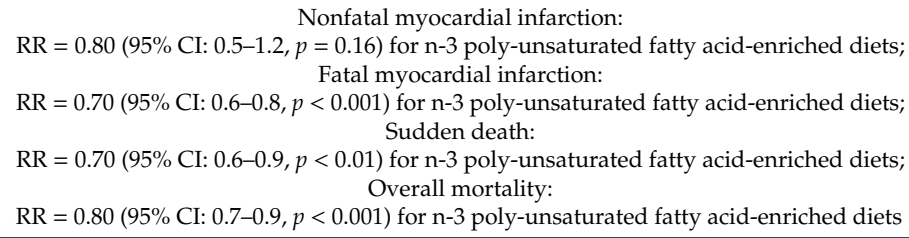 \\
\hline Rizos, 2012, [103] & $\begin{array}{c}\text { Meta-analysis from } 20 \text { case-control } \\
\text { studies }\end{array}$ & $\begin{array}{l}34,388 \text { patients in the treatment groups and } 34,292 \\
\text { patients in the control groups }\end{array}$ & $\begin{array}{c}\text { All-cause mortality: } \\
\mathrm{RR}=0.96(95 \% \text { CI: } 0.91-1.02) \text { for } \mathrm{n}-3 \text { poly-unsaturated fatty acids; } \\
\text { Cardiac death: } \\
\text { RR }=0.91(95 \% \text { CI: } 0.85-0.98) \text { for } \mathrm{n}-3 \text { poly-unsaturated fatty acids; } \\
\text { Sudden death: } \\
\mathrm{RR}=0.87(95 \% \text { CI: } 0.75-1.01) \text { for } \mathrm{n}-3 \text { poly-unsaturated fatty acids; } \\
\text { Myocardial infarction: } \\
\mathrm{RR}=0.89(95 \% \text { CI: } 0.76-1.04) \\
\text { for } \mathrm{n}-3 \text { poly-unsaturated fatty acids; } \\
\text { Stroke: } \\
\mathrm{RR}=1.05(95 \% \text { CI: } 0.93-1.18) \\
\text { for } \mathrm{n}-3 \text { poly-unsaturated fatty acids }\end{array}$ \\
\hline
\end{tabular}


Table 2. Cont.

\begin{tabular}{|c|c|c|c|}
\hline Author and Year of Publication & Study Design & Sample Size & Risk of Mortality \\
\hline Kwak, 2012, [104] & $\begin{array}{l}\text { Meta-analysis from } 14 \text { placebo-control } \\
\text { trials }\end{array}$ & $\begin{array}{l}10,226 \text { patients in the treatment groups and } 10,259 \\
\text { patients in the control groups }\end{array}$ & 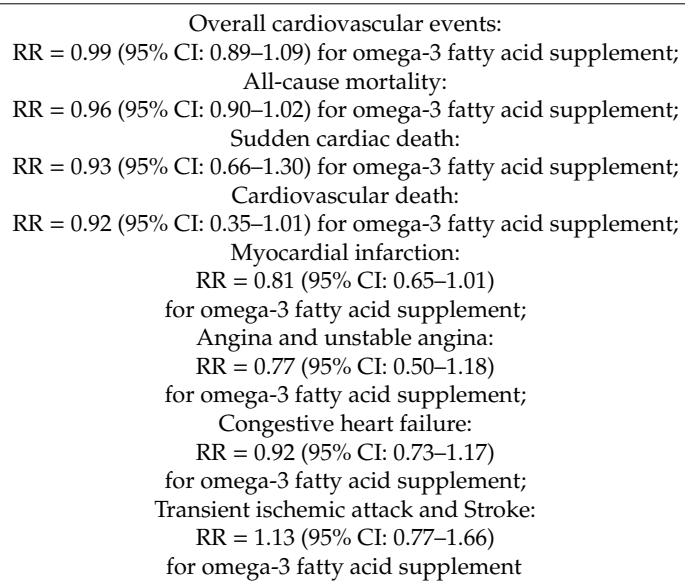 \\
\hline $\begin{array}{l}\text { Agency for Healthcare Research and } \\
\text { Quality, 2016, [105] }\end{array}$ & $\begin{array}{c}\text { Meta-analysis from } 61 \text { randomized } \\
\text { controlled trials and } 37 \text { longitudinal } \\
\text { observational } \\
\text { studies }\end{array}$ & $\begin{array}{l}\text { No available data about sample sizes of cohorts } \\
\text { examined }\end{array}$ & $\begin{array}{c}\text { All-cause death: } \\
\text { HR = } 0.97 \text { (95\% CI: 0.92-1.03) } \\
\text { for EPA + DHA; } \\
\text { Major Adverse Cardiovascular Events: } \\
\text { HR = } 0.96 \text { (95\% CI: 0.91-1.02) } \\
\text { for EPA + DHA; } \\
\text { Myocardial infarction: } \\
\text { HR = } 0.88 \text { (95\% CI: 0.77-1.02) } \\
\text { for EPA + DHA; } \\
\text { Cardiovascular Disease Death: } \\
\text { HR = } 0.92(95 \% \text { CI: 0.82-1.02) } \\
\text { for EPA + DHA; } \\
\text { Sudden Cardiac Death: } \\
\text { HR }=1.04 \text { (95\% CI: } 0.92-1.17) \text { for EPA + DHA; } \\
\text { Stroke: } \\
\text { HR = } 0.98 \text { (95\% CI: } 0.88-1.09) \\
\text { for EPA + DHA }\end{array}$ \\
\hline
\end{tabular}


Table 2. Cont.

\begin{tabular}{|c|c|c|c|}
\hline Author and Year of Publication & Study Design & Sample Size & Risk of Mortality \\
\hline Zhang, 2018, [106] & Prospective cohort study & $\begin{array}{l}\text { Total and cause-specific } \\
\text { Mortality from a cohort of } 240,729 \text { men and } 180,580 \\
\text { women }\end{array}$ & 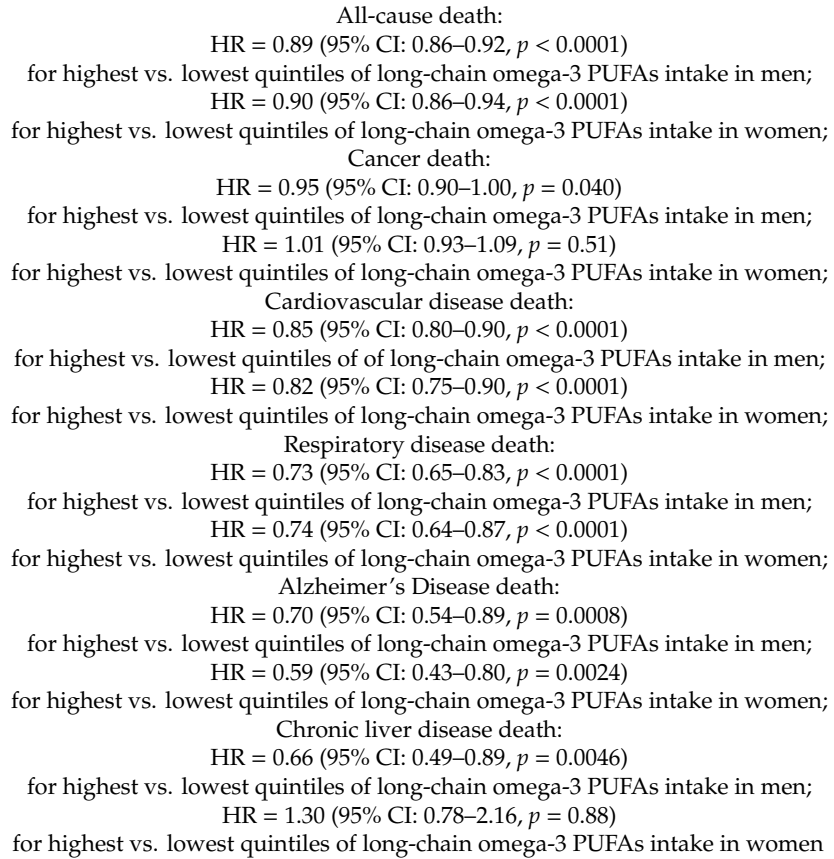 \\
\hline
\end{tabular}


Zhang et al. conducted a large perspective cohort study involving 240,729 men and 180,580 women [106], who were prospectively followed for 16 years to examine the associations of fish and long chain omega-3 Poly-unsaturated Fatty Acids (LCn-3 PUFAs) intakes with total and cause-specific mortality.

They found that comparing the highest with the lowest quintiles of fish and LCn-3 PUFAs intake, men had lower total mortality (Fish intake Multivariable HR: 0.91, 95\% CI: 0.89-0.94, $p<0.0001$; LCn-3 PUFAs Multivariable HR: 0.89, 95\% CI: 0.86-0.92, $p<0.0001$ ), lower cardiovascular disease (CVD) mortality (Fish intake Multivariable HR: 0.90, 95\% CI: 0.85-0.94, $p<0.0001$; LCn-3 PUFAs Multivariable HR: $0.85,95 \%$ CI: 0.80-0.90, $p<0.0001$ ), lower cancer mortality (Fish intake Multivariable HR: 0.94, 95\% CI: 0.90-0.99, $p=0.038$; LCn-3 PUFAs Multivariable HR: 0.95, 95\% CI: 0.90-1.00, $p=0.040$ ), lower respiratory disease mortality (Fish intake Multivariable HR: 0.80, 95\% CI: 0.72-0.89, $p<0.0001$; LCn-3 PUFAs Multivariable HR: 0.73, 95\% CI: 0.65-0.83, $p<0.0001$ ), lower Alzheimer's disease mortality (Fish intake Multivariable HR: 0.76, 95\% CI: 0.61-0.95, $p=0.0028$; LCn-3 PUFAs Multivariable HR: 0.70, 95\% CI: 0.54-0.89, $p=0.0008$ ), and lower chronic liver disease mortality (Fish intake Multivariable HR: 0.63, 95\% CI: 0.47-0.83, $p=0.0013$; LCn-3 PUFAs Multivariable HR: 0.66, 95\% CI: 0.49-0.89, $p=0.0046$ ).

Similarly, comparing the highest with the lowest quintiles of fish and LCn-3 PUFAs intake, women had lower total mortality (Fish intake Multivariable HR: 0.92, 95\% CI: 0.88-0.95, $p<0.0001$; LCn-3 PUFAs Multivariable HR: 0.90, 95\% CI: 0.86-0.94, $p<0.0001$ ), lower CVD mortality (Fish intake Multivariable HR: 0.90, 95\% CI: 0.83-0.97, $p=0.0034$; LCn-3 PUFAs Multivariable HR: $0.82,95 \%$ CI: $0.75-0.90, p<0.0001$ ), lower respiratory disease mortality (Fish intake Multivariable HR: $0.81,95 \% \mathrm{CI}$ : 0.71-0.92, $p<0.0001$; LCn-3 PUFAs Multivariable HR: 0.74, 95\% CI: 0.64-0.87, $p<0.0001$ ), and lower Alzheimer's disease mortality (Fish intake Multivariable HR: 0.62, 95\% CI: 0.48-0.80, $p<0.0001$; LCn-3 PUFAs Multivariable HR: 0.59, 95\% CI: 0.43-0.80, $p=0.0024$ ). Authors explained the discrepancies with the previous studies because of the limited statistical power of those previous small-scale studies. Moreover, another cause could be partially due to different cooking methods, as fried fish which is common in North American and European countries, may produce trans-fatty acids, oxidation of PUFAs, advanced glycation products (AGEs) and increase energy density, which counteract or even reverse the beneficial effects of nutritional ingredients in fish. They found a positive correlation between fried fish intake and mortality from all causes (P-trend $=0.011), C V D(P$-trend $=0.019)$, respiratory disease (P-trend $=0.031$ ) and infections (P-trend $=0.020$ ) in women. They did not find any significant relationship between intakes of fish and LCn-3 PUFAs and total mortality among participants with diabetes or $\mathrm{BMI} \geq 30$.

After examining findings from the Randomized Controlled Trials (RCT) concerning the prevention of CHD among patients at high CVD risk, coauthors of the Science Advisory from the American Heart Association [107] concluded that omega-3 PUFA supplements might reduce CHD death, by a reduction of sudden cardiac death, among patients with prior CHD. Nevertheless, the treatment does not reduce the incidence of recurrent nonfatal myocardial infarction. Because the benefit outweighs any risk of treatment, the majority of coauthors concluded that treatment with omega-3 PUFA supplements is reasonable for the secondary prevention of CHD death (Class IIa Recommendation); a minority of coauthors preferred a lower strength of recommendation for treatment of patients with this indication (Class IIb Recommendation).

In addition, coauthors examined results from the GISSI-HF RCT [108]. This RCT showed that, among patients with chronic heart failure with reduced ejection fraction, the omega-3 PUFA supplementation reduced the risk of total mortality (death resulting from any cause) by $9 \%$ (RR, 0.91 ; $95 \% \mathrm{CI}, 0.833-0.998 ; p=0.041)$ and the risk of cardiovascular-related hospitalizations or death by $8 \%$ (RR, 0.92; 95\% CI, 0.849-0.999; $p=0.009$ ).

They concluded that, although based on a single, large RCT, treatment with omega-3 fatty acids could be reasonable in the secondary prevention of heart failure-related hospitalizations and death among patients with heart failure with reduced ejection fraction (Class IIA, Recommendation). 
Nevertheless, the coauthors recommended the need for additional RCTs among patients with heart failure and preserved ejection fraction to confirm the strength of the Recommendation.

Regarding the association between the intake of omega-3 polyunsaturated fatty acids with the reduction of the incidence of cardiovascular disease and stroke and other aging-related diseases, Qi et al. [109] showed that treatment with alpha-linolenic acid (ALA), produced a 30\% increase in mean lifespan in Caenorhabditis elegans. Authors showed that ALA treatment enhanced the lifespan of the wild-type worms by activating the NHR-49/PPAR $\alpha$ and SKN-1/Nrf2 transcription factors. Specifically, ALA activated NHR-49 to promote the expression of genes involved in the b-oxidation of lipids. ALA exposure to air also causes oxidation of ALA in a group of compounds called oxylipins. The activation of SKN-1 by oxylipins improves longevity. This study has shown that omega-3 fatty acids slow aging; this effect can be due to the association of the effects of both omega-3 fatty acids and the oxylipin metabolites. The authors suggest the hypothesis that in humans, the healthy benefits of omega- 3 fatty acids intake could also derive from the production of oxylipin.

\section{Mediterranean Diet Increases Lifespan and Improves Aging}

Two key points are known: firstly, that most of the factors that determine lifespan are purely environmental, including diet; secondly, a CR that guarantees an adequate supply of all nutrients can prolong the life span of rodents; this effect was also demonstrated in other organisms, such as yeast, worms, flies, fish and spiders [110]. This CR paradigm has been very useful to clarify the molecular pathways that modulate aging, including the insulin-like growth factor- 1 and insulin signaling pathway, the sirtuin pathway, the AMP-activated protein kinase pathway and the mammalian target of rapamycin pathway, all of which interact [52,111]. Currently, there are many substantial proofs that the combinations of $\mathrm{CR}$ and exercise protect against multiple molecular and cellular damages, which are the basis of the functional decline associated with aging. On the contrary, overeating and a sedentary lifestyle accelerate the functional decline associated with aging, increasing the risk of diseases. CR and physical activity increase the body's resistance to environmental stressors and allow it to maintain its physiological function. However, in conditions of low resilience, chronic diseases, disability and frailty certainly compromise health, and consequently, the life span. In all these cases, CR not only has no beneficial effects, it also reduces the immune defenses, making response to infection inefficient and delaying the healing of wounds or fractures, reducing the resilience dramatically. Only short-term refeeding can reverse the detrimental effects of CR [112] (Figure 4). Trichopoulou et al. [84] have first proven substantially that a dietary pattern based on the MD has positive effects on life span in the elderly. They showed that a greater adherence to the MD leads to a significant reduction in mortality. More precisely, the authors showed that a greater adherence to the MD, as assessed by a semiquantitative questionnaire on food intake, was associated with a risk of death of $17 \%$ for an increase in one unit and over $50 \%$ for an increase of four units. Further evidence confirmed the association between lifestyle in middle age with successful aging and prevention against the onset of disability, frailty, and other non-communicable diseases, including cancer, and dementia [113]. It is, of course, the long-term effect of beneficial behavioral factors in middle-aged adults that contribute to successful aging, where, by successful aging, we mean the absence of important chronic diseases, severe disabilities and the preservation of cognitive functions, through the primary prevention of the onset of frailty. In contrast, a "Western" food model, which is characterized by a high intake of fried and sweet foods, processed foods and red meats, refined grains and fat-rich dairy products, is associated with a high prevalence of diseases and aging-related disabilities [7-9,114]. The EPIC study [115] examined the association between adherence to the MD pattern and life expectancy among 74,607 old men and women from nine European countries. The authors used a modified version of the MDS to evaluate adherence to the MD model: to calculate the monounsaturated/saturated lipid ratio, in the numerator, instead of monounsaturated lipids, the sum of monounsaturated and polyunsaturated lipids was used. In this modified MDS, both monounsaturated and polyunsaturated fatty acids are included in the numerator of the lipid ratio. The score range extends from zero (minimal adherence) to 
nine (maximal adherence). This change allowed the MDS score to be applied to the populations of areas other than the Mediterranean Sea basin, where notably, intake of monounsaturated fatty acids from olive oil is very low. The authors showed that for an increase of two units in the modified MDS, a reduction of $8 \%$ (95\% CI: $3 \%$ to $12 \%$ ) was observed for all-cause mortality. This association was naturally more evident in Greece and Spain, where the modified MDS corresponded to the traditional $\mathrm{MD}$, which is followed uniformly by the whole population. However, the application of the modified MDS allowed the authors to correct any heterogeneity between countries in the association with the overall mortality scores. In Italy, most death cases occurred in northern Italy, where the traditional diet cannot be considered as an MD.

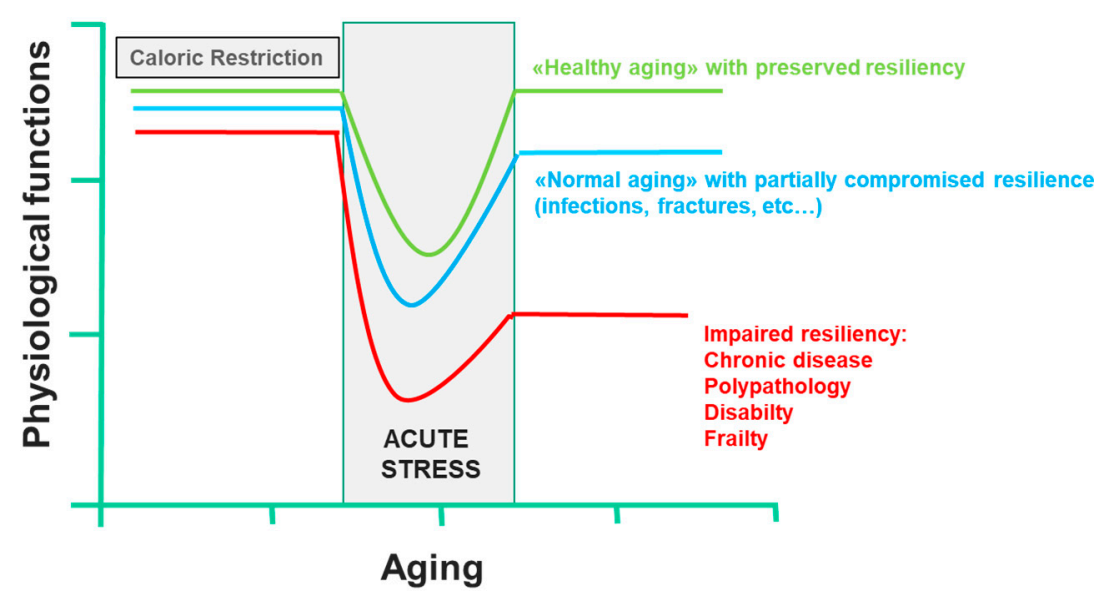

Figure 4. Effect of caloric restriction on aging and on the development of frailty (line 433).

Few studies have examined the association between lifestyle and mortality among the elderly in developing countries. Shi et al. [116] analyzed data from the Chinese Longitudinal Healthy Longevity Survey (CLHLS), which involved 8959 participants aged 80 or over, in order to evaluate an association between eating habits, lifestyle factors and mortality for all causes. The authors showed that everyday fruit and vegetable consumption was significantly associated with a lower risk for global mortality $(\mathrm{HR}=0.85 ; 95 \%$ CI: 0.77-0.92; $p<0.01 ; \mathrm{HR}=0.74 ; 95 \%$ CI: 0.66-0.83; $p<0.01$, respectively). Conversely, intake of salt-preserved vegetables was associated with a higher risk of all-cause mortality $(\mathrm{HR}=1.10$; 95\% CI: 1.03-1.18; $p<0.001$ ). Based on these results, the authors developed a "healthy lifestyle score" based on three factors: daily intake of fruit, vegetables and regular physical activity. For each positive response to each of the three lifestyle factors, a score of 1 was assigned, for a total maximum score of 3 . The subjects who led a healthier lifestyle, who are the subjects who totaled three points, had a median survival of another two years, even in the presence of chronic diseases. All the studies examined above are summarized in Table 3. 
Table 3. Mediterranean diet components and healthy aging.

\begin{tabular}{|c|c|c|c|}
\hline Author and Year of Publication & Study Design & Sample Size & Risk of Mortality \\
\hline Trichopoulou, 1995, [85] & Prospective cohort study & 91 men and 91women & $\begin{array}{c}\text { Mortality Rate: } \\
\mathrm{RR}=0.83 \text { (95\% CI: } 0.69-0.99, p=0.04) \text { for high adherence to MD }\end{array}$ \\
\hline Britton, 2008, [7] & Longitudinal cohort study & 4140 men and 1823 women & $\begin{array}{c}\text { Likelihood of Successful Aging for men: } \\
\text { OR }=1.52 \text { (95\% CI: 1.34-1.72, } p<0.001) \text { for socioeconomic position } \\
\text { OR }=1.19 \text { (95\% CI: } 1.06-1.33, p=0.003) \text { for early-life factors } \\
\text { OR }=1.29 \text { (95\% CI: } 1.16-1.44, p<0.001) \text { for health behaviours } \\
\text { OR }=1.12 \text { (95\% CI: } 1.01-1.24, p=0.03) \text { for psychosocial factors } \\
\text { Likelihood of Successful Aging for women: } \\
\text { OR }=1.58 \text { (95\% CI: } 1.31-1.92, p<0.001) \text { for socioeconomic position. } \\
\text { OR }=1.23 \text { (95\% CI: } 1.01-1.49, p=0.04) \text { for early-life factors } \\
\text { OR }=1.29 \text { (95\% CI: } 1.09-1.54, p=0.003) \text { for health behaviours } \\
\text { OR }=1.10 \text { (95\% CI: } 0.94-1.28, p=0.25 \text { ) for psychosocial factors }\end{array}$ \\
\hline Akbaraly, 2013, [8] & Longitudinal cohort study & 3775 men and 1575 women & 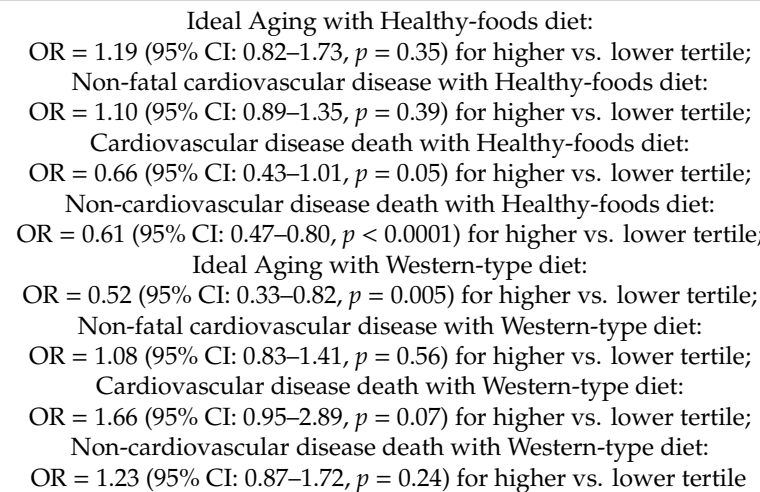 \\
\hline
\end{tabular}


Table 3. Cont.

\begin{abstract}
Author and Year of Publication
\end{abstract}
Sample Size

Risk of Mortality

Healthy aging and component of healthy aging, according to Alternative Healthy Eating Index-2010:

Healthy aging: $\mathrm{OR}=1.34(95 \% \mathrm{CI}: 1.09-1.66, p<0.001)$ for higher vs. lower quintile; No chronic disease: $\mathrm{OR}=1.01$ (95\% CI: $0.97-1.05, p=0.26$ ) for higher vs. lower quintile No cognitive impairment: OR $=0.99$ ( $95 \%$ CI: $0.97-1.01, p=0.09$ ) for higher vs. lower

quintile;

Ci:11-1.36, $p<0.001)$ for higher vs.

$\begin{aligned} \text { No impairment of physical function: } \mathrm{OR}=1.23(95 \% & \mathrm{C} \text { lower quintile }\end{aligned}$

Samieri, 2013, [9] C 1171 “Healthy agers" vs. 9499 “Usual agers"

quintile;

Healthy aging and component of healthy aging, according to MD:

Healthy aging: $\mathrm{OR}=1.46(95 \%$ CI: $1.17-1.83, p=0.0022)$ for higher vs. lower quintile; No chronic disease: OR $=1.04$ ( $95 \%$ CI: $1.00-1.09, p=0.13$ ) for higher vs. lower quintile No cognitive impairment: OR $=0.97$ (95\% CI: $0.95-1.00, p=0.02$ ) for higher vs. lower

No impairment of physical function: $\mathrm{OR}=1.14(95 \% \mathrm{CI}: 1.03-1.26, p=0.005)$ for higher vs. lower quintile;

No limitation of mental health: OR $=1.12$ (95\% CI: 1.04-1.20, $p<0.001)$ for higher vs. lower quintile

Mortality ratios (MR) for all countrie:

$\mathrm{MR}=0.92(95 \%$ CI: $0.88-0.97, p$ value for heterogeneity $=0.328)$ for 2 unit increase of

Trichopoulou, 2005, [115]

Multicentre, prospective cohort study

24,545 men and 50,062 women from the EPIC-elderly cohort

3567 men and 5392 women from the

Shi, 2015, [116]
Longitudinal cohort study Survey (CLHLS) 
It has been confirmed by substantial evidence that MD reduces mortality from many chronic diseases, such as cardiovascular diseases, neurodegenerative diseases and even cancer [117]. All this is due to the synergistic action of the different nutritional elements of the MD. Several papers studied the functions of the nutritive components of MD in preventing cancer, obesity, cardiovascular and neurodegenerative diseases. Serra-Majem and Estruch [118] further confirmed these favorable effects of the MD in a systematic review. They confirmed the favorable effects of MD in reducing cholesterol and triglyceride levels, improving insulin resistance and increasing antioxidant capacity. In addition, the authors confirmed the favorable effects of MD on endothelium vasodilatation, metabolic syndrome, and on reducing myocardial and cardiovascular mortality and cancer incidence both in obese patients and in those with previous myocardial infarction. Rees and colleagues [119], in their systematic review of 11 randomized clinical trials in 52,044 subjects, further confirmed that the MD reduces cardiovascular disease by reducing cholesterol levels, especially LDL levels. In a further review, Sleiman et al. [120] confirmed that MD has favorable effects in reducing cardiovascular disease by reducing both fasting blood sugar and HbA1c.

Bonaccio et al., analyzing data from the Moli-sani study [121], which involved 24,325 subjects from the Molise Region, in Southern Italy, further showed that an MD pattern, that is the consumption of healthy foods with a high content of antioxidants, vitamins and phytochemicals, was significantly associated with a reduction of the 10-year cardiovascular risk. This favorable result was related to lowering levels and of glucose, lipids, CRP plasma levels, and blood pressure.

From a strictly biological point of view, there is a lot of evidence that show how nutrition works by modulating numerous interconnected cellular processes, implicated both in carcinogenesis and in inflammatory responses, or in the production of free radicals, or in the expression of inflammatory cytokines and the eicosanoid pathway [122], for example through the down-regulation of gene expression of the NF- $\mathrm{KB}$ transcription factor. The MD can also have a positive impact on the so-called "inflammaging" through the epigenetic mechanism (which includes chromatin remodeling, DNA methylation and miRNAs) or through the preservation of intestinal microbiota homeostasis [117].

Regarding the relationship between eating habits and mental health [123], it has been established that a diet with a high intake of vegetables, fruit, legumes as the main source of protein, olive oil as the main source of lipids, fish as the main source of animal protein, grains, nuts and seeds provides a wide range of nutrients, including vitamin B, omega-3 fatty acids and antioxidants [124]. The antioxidants contained in foods can protect brain cells from oxidative membrane damage, which has been involved in the pathogenesis of several psychiatric disorders, including depression [125], and in the pathogenesis of dementia. Regarding omega-3s, docosahexaenoic acid is essential for brain development and is highly concentrated in the brain structure. Omega-3s and vitamins are involved in a variety of brain functions, such as neurotransmitter synthesis, the development and maintenance of neuronal cells, and mechanisms to protect the blood-brain barrier [124].

\section{Diet Patterns and "Inflammaging"}

"Inflammaging" has been defined as the state of chronic activation of a low-grade inflammatory state in the elderly [126]. It has been hypothesized that it could be prodromal at the beginning of cognitive decline [127] and polypathology [128]. Most chronic diseases with a high prevalence in the elderly can most likely be correlated with an alteration of the immune response and inflammation [129]. The long-term pro-inflammatory chronic condition adversely affects survival, helping to determine a significant decline in physical performance, as well as the onset of cognitive symptoms and depression, up to defining a condition of high risk of mortality $[130,131]$. The role of nutrition in these processes is of great importance. While acute inflammation can contribute to increasing energy needs, comorbidities and consequent chronic low-grade inflammation are key determinants of loss of appetite and reduced nutrient intake, also known as "anorexia of aging", thus leading to the onset of "malnutrition—related disease" [132]. The altered metabolic balance caused by malnutrition and nutrient reduction has been associated with the onset of loss in mass and muscle strength, frailty and functional dependency, 
resulting in disability. This creates a vicious circle between the reduced nutritional intake condition and the resulting state of a greater energy demand, determining an unfavorable prognostic pathway [133]. This condition of hyper-catabolism becomes more evident in the presence of a pathological situation in a critical state, characterized by a poor response to nutritional intervention [134]. In elderly people hospitalized for acute illness or chronic disease reactivation, the degree of inflammation, more than nutritional status, is decisive on prognosis [135]. More importantly, the low-intensity chronic hyper-catabolism status present outside the acute phase is closely related to inflammation. This condition, known as "anabolic resistance", leads to non-optimal protein synthesis in skeletal muscle in response to physiological stimuli and is one of the main causative factors of sarcopenia [136].

\section{Mediterranean Diet Confers Protection Against Sarcopenia}

An extensive amount of evidence showed that a Mediterranean Diet pattern, or a diet with a predominant intake of vegetables, fruits, vegetable protein from legumes, and omega- 3 fatty acids, especially animal protein from fish, could reduce the risk of experiencing osteoporosis and sarcopenia in the elderly. The results from a cross-sectional study involving 2570 women aged 18 to 79 years from the United Kingdom [137], have shown that a high adherence to the Mediterranean diet was significantly related to increased muscle mass and legs explosive power (LEP, watts $/ \mathrm{kg}$ ), with a significant difference of $1.7 \%$ for FFM\% (fat-free mass/weight $\times 100$ ) and $9.6 \%$ for LEP (trend $p<0.001$ ).

A cross-sectional study conducted on 327 subjects aged over 65 from Taipei in Taiwan [138] showed that a high daily intake of mainly plant-based proteins is protective against the loss of muscle mass. As for total protein intake, subjects in the lower quartile had a greater risk of losing muscle mass than those in the upper quartile $(\mathrm{OR}=3.03 ; 95 \% \mathrm{CI}$ : 1.37-6.72). Concerning vegetable proteins intake, subjects in the lower quartile, similarly, had a higher risk of loss of muscle mass than subjects in the higher quartile $(\mathrm{OR}=2.34,95 \% \mathrm{CI}: 1.14-4.83)$. With the aim to study the presence of relationships between nutrient and micronutrient intake and quality of life among sarcopenic and non-sarcopenic elderly people, the Maastricht Sarcopenia (MaSS) study [139] (227 subjects) and the PROVIDE study [140] (136 subjects) were independently conducted on two Dutch populations. Both studies showed that sarcopenics differed in certain nutritional assumptions and biochemical nutrient status compared to non-sarcopenic subjects. As regard the MaSS Study, sarcopenic subjects had a low intake of protein $(p=0.048), \mathrm{n}-3$ fatty acids $(p=0.022)$, folic acid $(p=0.016)$ and magnesium $(p=0.024)$, respectively, and a high intake of ALA ( $p=0.018$ ) (both dietary and supplement intakes were included in the study). In addition, the sarcopenic subjects had a low intake of vitamin B6 from the diet $(p=0.005)$; no significant differences were observed among sarcopenics and non-sarcopenics after including dietary supplements in the analysis $(p=0679)$. Regarding the PROVIDE study, all the sarcopenic subjects did not practice physical activity $(p<0.001)$ and had a lower quality of life compared to non-sarcopenic subjects $(p<0.001)$. Compared to the non-sarcopenic group, the sarcopenic group had a lower intake of proteins $(p=0.044)$, vitamin D $(p=0.007)$, vitamin B-12 $(p=0.011)$, magnesium $(p=0.015)$, phosphorus $(p=0.014)$ and selenium $(p=0.039)$. Lastly, Barrea et al. [141], in their cross-sectional study conducted in a sample of community-dwelling elderly women, evidenced a positive association between the adherence to the MD and muscle functional capacity measured by the Hand Grip Strength (HGS), where cut-point used for low HGS in women was $<20 \mathrm{~kg}$. In particular, authors showed that women with $\mathrm{HGS}<20 \mathrm{Kg}$ had a significantly lower percentage of energy intake from protein $(p<0.001)$, from carbohydrate $(p<0.001)$, and from unsaturated fat $(p=0.018)$ and n-3 PUFA $(p=0.031)$, and a significantly higher total fat $(p<0.001)$ and cholesterol intake $(p=0.006)$ than women with HGS $>$ cut-point. They reported a strong correlation between high adherence to MD and high muscle capacity $(p=0.003)$.

All the evidence concerning the association between diet patterns and muscle mass and muscle strength is summarized in Table 4. 
Table 4. Mediterranean diet pattern, muscle mass and muscle strength.

\begin{tabular}{|c|c|c|c|}
\hline Author and Year of Publication & Study Design & Sample Size & Muscle Mass and Muscle Strength \\
\hline Kelaiditi, 2016, [137] & Cross-sectional study & 2570 women from the Twins UK study & 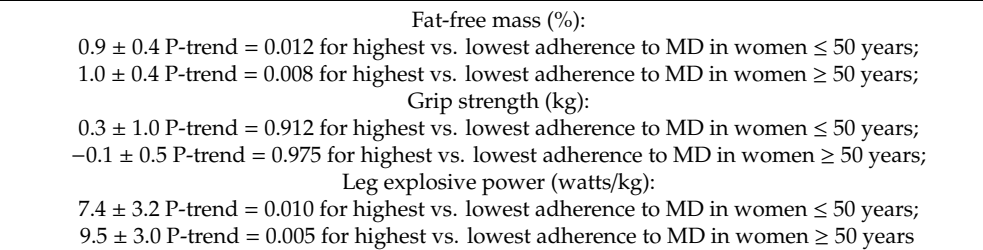 \\
\hline Huang, 2016, [138] & Cross-sectional study & 327 community-dwelling elderly people & $\begin{array}{c}\text { Odds ratios for total protein and vegetable protein density for Low Muscle Mass (LMM): } \\
\text { OR = 3.11 (95\% CI: } 1.42-6.84, p=0.005) \text { for lowest vs. highest total protein density intake; } \\
\text { OR = } 2.50 \text { (95\% CI: } 1.22-5.10, p=0.012) \text { for lowest vs. highest vegetable protein density intake; } \\
\text { Adjusted least square (LS) means for LMM vs. normal groups: } \\
14.5 \text { vs. } 15.5, p=0.008 \text { for total protein density intake; } \\
7.0 \text { vs. } 8.2, p=0.002 \text { for vegetable protein density intake }\end{array}$ \\
\hline Ter Borg, 2016, [139] & Cross-sectional study & $\begin{array}{l}227 \text { community-dwelling adults aged } \\
\text { over } 65 \text { years from the Maastricht } \\
\text { Sarcopenia Study }\end{array}$ & 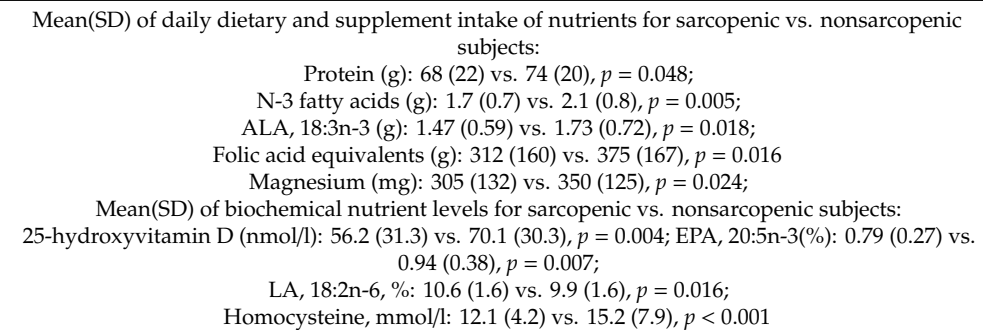 \\
\hline Verlaan, 2017, [140] & $\begin{array}{l}\text { Matched case-control observational } \\
\text { study }\end{array}$ & $\begin{array}{l}66 \text { sarcopenic older adults vs. } 66 \\
\text { non-sarcopenic older adults from the } \\
\text { PROVIDE Study }\end{array}$ & $\begin{array}{c}\text { Mean (SD) of daily dietary nutrient intakes for sarcopenic vs. nonsarcopenic subjects: } \\
\text { Protein (g): } 72.5(19.6) \text { vs. } 75.3(20.7), p=0.359 ; \\
\text { Protein }(\mathrm{g} / \mathrm{kg}): 0.99(0.24) \text { vs. } 1.09(0.29), p=0.044 \\
\text { Carbohydrate (g): } 212(61) \text { vs. } 208(76), p=0.906 ; \\
\text { Total Fat (g): } 63.3(19.0) \text { vs. } 65.8(22.1), p=0.403 ; \\
\text { Vitamin B-12 (g): } 3.9(2.6) \text { vs. } 5.3(3.6), p=0.011 \\
\text { Vitamin D (mg): } 2.6(2.1) \text { vs. } 4.0(3.4), p=0.007 \\
\text { Magnesium (mg): } 260 \text { (96) vs. } 295(86), p=0.015 ; \\
\text { Phosphorus (mg): } 1196(330) \text { vs. } 1325(338), p=0.014 \\
\text { Selenium (mg): } 39.1 \text { (17.1) vs. } 46.5(21.2), p=0.039\end{array}$ \\
\hline Barrea, 2019, [141] & Cross-sectional observational study & $\begin{array}{l}84 \text { not hospitalized elderly women from } \\
\text { the PERSSILAA project }\end{array}$ & 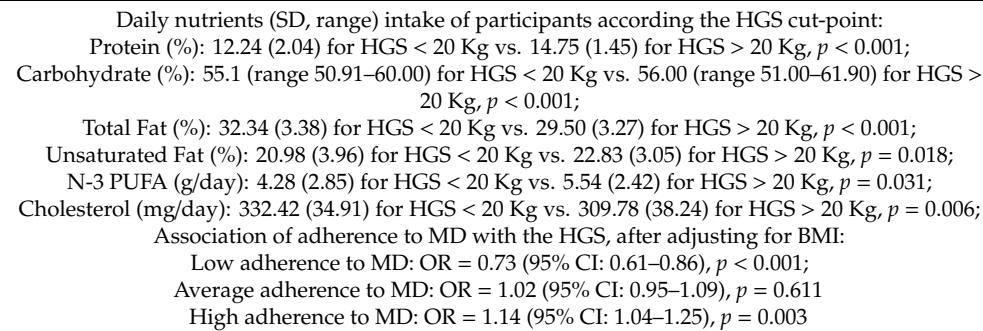 \\
\hline
\end{tabular}


It must, however, be pointed out that the above studies relate the high intake of proteins, especially of vegetable origin, with a reduced risk of reduction in mass and muscle strength; the studies that considered frankly sarcopenic patients showed that this category of subjects presented a reduced protein intake, omega- 3 fatty acids, and micronutrients, and a high ALA intake. It would therefore be an exaggeration to state that the Mediterranean diet certainly reduces the risk of developing sarcopenia.

In this regard, a review by Granic et al. [142] reiterated the beneficial effects of the Mediterranean diet towards the reduction of strength and muscle mass and towards the reduction of walking speed. Nevertheless, the authors suggest the need to harmonize methods for defining dietary models (i.e., Mediterranean diet vs. Healthy Eating Index), through cross-validation, together with the need for specially designed studies on different elderly populations with a longer follow-up to reach a higher level of evidence.

\section{Mediterranean Diet Maintains Health Status and Prevents from the Onset of Frailty}

Plenty of studies showed a fact already known, namely that a decisive factor regarding the development of frailty is represented by eating habits. It is known that protein supplementation, combined with physical activity with resistance exercises, are an effective way to counteract muscle weakness and physical frailty in elderly people [143].

Most authors agree that the Mediterranean diet is the best diet model that we can propose to maintain health, or to get old with a lower incidence of frailty syndrome, or disability because of chronic diseases and physical and cognitive impairment in old age. This is due to the daily intake of the main components of the MD [110,144,145].

The results of the InCHIANTI study showed that high adherence to MD was associated with better mobility performance. [146]. That is, subjects with a higher adherence to MD experienced a lower decrease in motor performance, therefore, a lower risk of developing disabilities at 3, 6 and 9 years of follow-up. Furthermore, in a subsequent study, older subjects with a high MD adherence presented a lower risk of developing frailty (OR $=0.26$; $95 \%$ CI: 0.07-0.98) [147]. Regarding the protective effects of n-3 PUFA, it is known that a diet rich in n-6 PUFA, which is a precursor of arachidonic acid, which is a substrate of the enzyme cyclo-oxygenase and lipo-oxygenase, and poor in n-3 PUFA (EPA and DHA), determines a pro-inflammatory state harmful to muscles or other tissues. The integration of fish oil into a group of Brazilian women involved in a randomized trial [148] produced a better performance in lower limb strength training exercises. In the same group which was trained with supplementation of fish oil intake in the diet, a greater improvement for chair-rising performances was observed. In a subsequent study, fish oil supplementation improved walking speed in a group of postmenopausal women [149]. Another study conducted on 417 old Japanese men [150] showed that a reduced dietary EPA or DHA intake was associated with reduced motor performance. The authors therefore suggested that fish oil supplementation has a particularly beneficial effect in training against resistance and may represent a therapeutic strategy in the prevention of sarcopenia in frail patients.

Reduced synthesis of muscle proteins in older sarcopenic derives from various factors such as reduced insulin or amino acid response [151,152]. Therefore, dietary interventions must be developed with the aim to compensate the altered synthesis of muscle proteins and to help to counteract muscular atrophy caused by periods of immobilization that are frequently observed in the elderly [153]. For example, in everyday life, the distribution of protein intake is very heterogeneous between different meals: usually, less than $10 \mathrm{~g}$ of protein is taken during breakfast, especially among frail elderly people. [154]. This implies that for about $18 \mathrm{~h}$, or the period between dinner and lunch, a frail elderly person is not getting enough protein. This explains why the anabolic response is compromised even if the daily protein intake is apparently adequate in people at risk. Results from a longitudinal study on a cohort of 690 non-institutionalized old people, from the InCHIANTI Study [155], confirmed that subjects following the traditional MD developed a significantly lower risk of frailty (OR $=0.30 ; 95 \% \mathrm{CI}$ : $0.14-0.66)$. Authors also confirmed that a high adherence to an MD pattern was associated with a lower risk of low physical activity (OR $=0.62 ; 95 \% \mathrm{CI}$ : $0.40-0.96)$ and low walking speed (OR $=0.48 ; 95 \% \mathrm{CI}$ : 
0.27-0.86). Furthermore, the results of the Seniors-ENRICA study [156] showed that high adherence to a "Prudent Pattern" diet model, that is characterized by a high intake of olive oil, vegetables, legumes, blue fish, and pasta, was related to a reduced risk of developing frailty (OR = 0.40; 95\% CI: 0.20-0.81; P-trend = 0.009). On the other hand, the high level of adherence to a "Westernized Pattern" diet, that is, with a high intake of very refined flour bread, fat-rich dairy products, red or processed meat, and a poor assumption of whole-grain products, of fruit, low-fat dairy products and vegetables, correlated with a high risk of frailty $(\mathrm{OR}=1.61 ; 95 \% \mathrm{CI}$ : 0.85-3.03; P-trend $=0.14)$. The authors also showed that a high adherence to the "Western Pattern" diet was associated with two of Fried's frailty criteria [13], namely reduction in walking speed $(\mathrm{OR}=1.85 ; 95 \% \mathrm{CI}$ : 1.19-2.87; P-trend $=0.007)$ and involuntary weight loss (OR = 2.12; 95\% CI: 1.22-3.70; P-trend =0.007).

Another Chinese study conducted on a cohort of 2724 people, men and women resident in the community, over the age of 65 , examined the relationship between eating habits and the incidence of frailty [157]. The semiquantitative FFQ-questionnaire was used to evaluate dietary intake [158,159]. The authors used the Dietetic-International Index (DQI-I) scale to evaluate the quality of the diet; in a range between 0 and 94, a high score indicates a better quality of the diet [160,161]. To assess adherence to the MD, the Mediterranean Diet Score (MDS) [162] was used. After adjustment for sex and age, the authors found a $41 \%$ reduction in the risk of frailty for every increase of 10 DQI-I units $(\mathrm{OR}=0.59$; 95\% CI: 0.42-0.85; $p=0.004)$. The model was also adjusted by Body Mass Index (BMI), energy intake, physical activity, education level, smoking status, alcohol use, depression, cognitive impairment, living alone and marital status at baseline. After this adjustment, the association was lower, if we consider not only the $\mathrm{OR}$ value, but also the $p$-value (OR $=0.69 ; 95 \% \mathrm{CI}: 0.47-1.02 ; p=0.056)$. It is interesting to note that the authors did not observe any association of MDS with frailty, among elderly Chinese people.

Two following studies showed the protective role of the MD from the development of frailty. The first study [163] was conducted on a French population from the Bordeaux cohort study of Three-City Study [164]. The semi-quantitative Food Frequency Questionnaire (FFQ) was used to evaluated food habits, while the MDS was used to evaluate the adherence to the MD [84]. A high adherence to the MD was associated, even in this study, with a reduced risk of developing frailty $(p=0.02)$. This significant decreased risk of developing frailty was also confirmed after adjusting by age, sex, marital status, education, BMI, diabetes, hypertension and cardiovascular disease history, polypharmacotherapy, cognitive functions by MMSE, and depression state. (OR =0.32; 95\% CI: 0.14-0.72, $p=0.006)$. The authors also demonstrated the association between high adherence to MD and a lower risk of frailty, considering three of Fried's criteria [13], namely poor muscle strength (OR $=0.44 ; 95 \%$ CI: $0.20-0.98$, $p=0.04)$, slowness (OR $=0.45 ; 95 \% \mathrm{CI}: 0.20-500.99, p=0.04)$ and low physical activity $(\mathrm{OR}=0$, 39, 95\% CI: 0.18-0.82; $p=0.01)$. The second study [165] involved an American population from the Osteoarthritis Initiative (OAI) [166,167], to investigate the association between the adherence to a MD pattern and the incidence of frailty. The Block Brief 2000 food frequency (FFQ) questionnaire [168] was used to analyze participants' diet patterns during the baseline appointment of the OAI visit. The Mediterranean diet score (aMED), validated by Panagiotakos et al. [169], was used to assess the adherence of participants to an MD model, based on the results of the FFQ. After adjusting by age, sex, race, body mass index, education, smoking habits, yearly income, physical activity level, co-morbidity and daily energy intake, authors showed that a high adherence to an MD pattern was significantly associated with a low risk of developing frailty $(\mathrm{HR}=0.71 ; 95 \% \mathrm{CI}: 0.50-0.99, p=0.047)$. It is interesting to observe the association, by the authors, of a low consumption of poultry with a greater risk of frailty $(\mathrm{HR}=1.34 ; 95 \% \mathrm{CI}: 1.07-1.67, p=0.009)$. All the evidence examined above are summarized in Table 5 . 
Table 5. Mediterranean diet components and frailty.

\begin{tabular}{|c|c|c|c|}
\hline $\begin{array}{l}\text { Author and Year of } \\
\text { Publication }\end{array}$ & Study Design & Sample Size & Risk of Frailty \\
\hline Milaneschi, 2011, [146] & $\begin{array}{c}\text { Prospective } \\
\text { population-based study }\end{array}$ & $\begin{array}{l}935 \text { community-living } \\
\text { subjects aged over } 65 \\
\text { years from the } \\
\text { InCHIANTI Study } \\
\text { cohort }\end{array}$ & $\begin{array}{l}\text { Adjusted odds of developing mobility } \\
\text { disability: } \\
\text { OR }=0.73 \text { (95\% CI: } 0.41-1.28, p=0.27) \\
\text { for highest vs. lowest adherence to } \\
\text { MD; } \\
\text { Decrease in SPPB scores at } 9 \text { years of } \\
\text { follow up: } \\
\text { Average Score }=0.9 \text { (SE }=0.41, \\
p=0.03 \text { ) for highest vs. lowest } \\
\text { adherence to MD; } \\
\text { Adjusted incidence of mobility } \\
\text { disability: } \\
\text { HR }=0.71 \text { (95\% CI: } 0.51-0.98, p=0.04) \\
\text { for highest vs. lowest adherence } \\
\text { to MD }\end{array}$ \\
\hline Bollwein, 2013, [147] & Cross-sectional study & $\begin{array}{l}192 \text { community-dwelling } \\
\text { volunteers aged over } 75 \\
\text { years }\end{array}$ & $\begin{array}{c}\text { Odds Ratio for Frailty: } \\
\text { OR }=0.19 \text { (95\% CI: } 0.05-0.82, \\
p=0.011) \text { for highest vs. lowest } \\
\text { adherence to MD }\end{array}$ \\
\hline Talegawkar, 2012, [155] & $\begin{array}{c}\text { Prospective } \\
\text { population-based study }\end{array}$ & $\begin{array}{l}690 \text { community-living } \\
\text { subjects aged over } 65 \\
\text { years from the } \\
\text { InCHIANTI Study } \\
\text { cohort }\end{array}$ & $\begin{array}{l}\text { Odds Ratio for Frailty: } \\
\text { OR }=0.30 \text { ( } 95 \% \text { CI: } 0.14-0.66) \text { for } \\
\text { highest vs. lowest adherence to MD }\end{array}$ \\
\hline Luz, 2015, [156] & Prospective cohort study & $\begin{array}{c}1872 \\
\text { non-institutionalized } \\
\text { subjects aged over } 60 \\
\text { years from the } \\
\text { Seniors-ENRICA cohort } \\
\text { Study }\end{array}$ & $\begin{array}{c}\text { Odds Ratio for Frailty: } \\
\text { OR }=0.40(95 \% \text { CI: } 0.20-0.81, \\
p=0.009) \text { for highest adherence to a } \\
\text { "prudent pattern" diet; } \\
0.40(0.20-0.81) 0.009 \\
\text { OR = } 1.61(95 \% \mathrm{CI}: 0.85-3.03, p=0.14) \\
\text { for highest adherence to a } \\
\text { "westernized pattern" diet }\end{array}$ \\
\hline Rahi, 2017, [163] & $\begin{array}{l}\text { Population-based } \\
\text { prospective cohort study }\end{array}$ & $\begin{array}{l}560 \text { non-institutionalized } \\
\text { subjects aged over } 65 \\
\text { years from the cohort of } \\
\text { Three-City-Bordeaux } \\
\text { Study }\end{array}$ & $\begin{array}{c}\text { Odds Ratio for Frailty: } \\
\text { OR }=0.32 \text { ( } 95 \% \text { CI: } 0.14-0.72, \\
p=0.006) \text { for highest vs. lowest } \\
\text { adherence to MD }\end{array}$ \\
\hline Veronese, 2017, [165] & $\begin{array}{l}\text { Population-based } \\
\text { prospective cohort study }\end{array}$ & $\begin{array}{c}1857 \text { men and } 2564 \\
\text { women from the The } \\
\text { Osteoarthritis Initiative } \\
\text { cohort Study }\end{array}$ & $\begin{array}{c}\text { Odds Ratio for Frailty: } \\
\text { OR }=0.71 \text { ( } 95 \% \text { CI: } 0.50-0.99 \\
p=0.047) \text { for highest vs. lowest } \\
\text { adherence to MD }\end{array}$ \\
\hline
\end{tabular}

\section{Conclusion Remarks on Nutrition and Frailty}

Aging is the result of an interaction between local and systemic environmental factors and involutional factors due to cell senescence. A healthy lifestyle in middle age, which includes a correct diet or even a slight reduction in caloric intake, predisposes to a low risk or absence of serious chronic diseases or to the decline of cognitive or physical functions in old age. This is the consequence of preserving the efficiency of the immune system, as well as, at the cellular level, the preservation of mitochondrial activity and the reduction of oxidative stress.

The frailty of the elderly is a condition characterized by an increased vulnerability to poor homeostasis resolution after a stress event, which increases the risk of negative outcomes, including falls, delirium and disability. Frailty must not be understood as an inevitable consequence of aging, but rather must be understood as a geriatric syndrome, or a "frailty syndrome", that results from the interaction of various factors, including aging-related physiological alterations, poly-pathology, malnutrition, and the negative impact of socio-environmental factors. The clinical course of frailty makes its association with the state of nutrition more evident (Figure 5). In physiological aging, it is 
usual to observe a decrease in lean mass and bone mineral density, while a smaller reduction in fat mass was observed.

\begin{tabular}{|c|c|}
\hline \multicolumn{2}{|c|}{ Predisposing causes } \\
\hline \multicolumn{2}{|c|}{$\begin{array}{ll}\text { - } & \text { Polypathology } \\
\text { - } & \text { Polypharmacy } \\
\text { - } & \text { Decline of psycho-physical functions } \\
\text { - } & \text { Decline of the functional reserve }\end{array}$} \\
\hline \multicolumn{2}{|c|}{ Clinical aspects of frailty } \\
\hline $\begin{array}{l}\text { Symptoms } \\
\text { - Weakness } \\
\text { - Fatigue } \\
\text { - Loss of appetite-Anorexia }\end{array}$ & 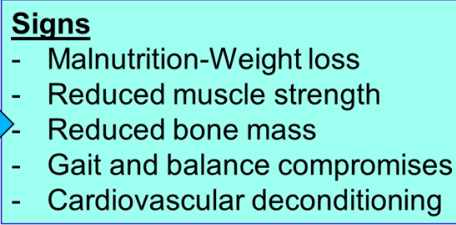 \\
\hline \multicolumn{2}{|c|}{ Consequences of frailty } \\
\hline $\begin{array}{ll}\text { - } & \text { Fractures } \\
\text { - } & \text { Wounds } \\
\text { - } & \text { Acute illness } \\
\text { - } & \text { Hospitalization }\end{array}$ & $\begin{array}{ll}\text { - } & \text { Disability } \\
\text { - } & \text { Addiction } \\
\text { - Institutionalization } \\
\text { - }\end{array}$ \\
\hline
\end{tabular}

Figure 5. The course and consequences of frailty (line 686).

Sarcopenia is the pathological aspect of reduction of strength and muscle mass, more evident in subjects of advanced or very advanced age; this is responsible for weakness and decreased physical activity. An inadequate protein intake, which is very common among the elderly, accelerates the progression of sarcopenia. [170]. Older people very often reduce the consumption of animal proteins due to difficulty in chewing due to edentulism and the reduction of the perception of taste and smell due to polypharmacy. The expression "anorexia of aging" refers to the significant reduction in energy intake, consequent to the loss of appetite, in elderly subjects, and with a further significant reduction in protein intake. Several other factors, such as insulin resistance or altered protein digestion and amino acid absorption, inhibit the stimulation of muscle protein synthesis in the elderly, even when the dietary protein intake is adequate [171].

Reducing food intake also leads to a lack of micronutrients, contributing to the development of frailty. Very frequently, low calcium and vitamin D values are observed in the elderly population, because of insufficient dietary intake and poor sun exposure. Vitamin D and calcium deficiency accelerate bone resorption. Very often, these are subjects that expose themselves little to sunlight, thus reducing the possibility of producing vitamin D in the skin; otherwise, they show very reduced physical activity, reducing the retention of bone calcium, stimulated mainly by physical exercise. This type of behavior is further aggravated by loneliness and isolation of the elderly, a consequence of depression or, in general, by the loss of health status.

Antioxidant properties of some foods play an important role in protecting or developing frailty. Even in healthy and dwelling living elderly, a slow and gradual reduction of antioxidant defenses has been observed [172], along with an increase in oxidative stress markers [173]. This condition was certainly due to the aging process itself but it could also be the result of reduced antioxidants dietary intake $[173,174]$. The physiological increase of oxidative stress is certainly a responsible component of the aging process; the pathological increase of oxidative stress, resulting in reduced defense processes, is an important causal factor in the development of specific conditions of frailty, including mainly the reduction of mass and bone strength [175] and the reduction of mass and strength muscle [176]. In conclusion, the cross-sectional and prospective studies described above provide further and convincing evidence about the connection between MD adherence, or between nutrient intake with antioxidant properties and the prevention of frailty. They also contribute to increase our understanding of the 
molecular mechanisms involved in the physiological aging process, or in the mechanisms of protection against frailty.

Author Contributions: C.C., F.B., A.L.B., G.V. equally contributed to the manuscript. All authors have read and agreed to the published version of the manuscript.

Funding: This research received no external funding.

Acknowledgments: This review paper has been endorsed by the "Fondazione Dieta Mediterranea, Ostuni, Italy" https://www.fondazionedietamediterranea.it/.

Conflicts of Interest: The authors declare no conflict of interest.

\section{References}

1. Population Structure and Ageing. Available online: http://ec.europa.eu/eurostat/statistics-explained/index. php/Population_structure_and_ageing (accessed on 1 June 2019).

2. Kinsella, K.; Phillips, D.R. Global Aging: The Challenge of Success; Population Bulletin; Population Reference Bureau: Washington, DC, USA, 2005; Volume 60.

3. United Nations. The World at Six Billion. Available online: www.un.org/esa/population/publications/ sixbillion/sixbilpart1.pdf (accessed on 1 June 2019).

4. Beard, J.R. The World report on ageing and health: A policy framework for healthy ageing. Lancet 2016, 387, 2145-2154. [CrossRef]

5. Beard, J.R.; Bloom, D.E. Towards a comprehensive public health response to population ageing. Lancet 2015, 385, 658-661. [CrossRef]

6. Age Wave, Sun America. Age Wave/Sun America Retirement Reset Study; Age Wave, Sun America: Los Angeles, CA, USA, 2011.

7. Britton, A.; Shipley, M.; Singh-Manoux, A.; Marmot, M.G. Successful aging: The contribution of early life and midlife risk factors. J. Am. Geriatr. Soc. 2008, 56, 1098-1105. [CrossRef]

8. Akbaraly, T.; Sabia, S.; Hagger-Johnson, G.; Tabak, A.G.; Shipley, M.J.; Jokela, M.; Brunner, E.J.; Hamer, M.; Batty, G.D.; Singh-Manoux, A.; et al. Does overall diet in midlife predict future aging phenotypes? A cohort study. Am. J. Med. 2013, 126, 411-419. [CrossRef] [PubMed]

9. Samieri, C.; Sun, Q.; Townsend, M.K.; Chiuve, S.E.; Okereke, O.I.; Willett, W.C.; Stampfer, M.; Grodstein, F. The association between dietary patterns at midlife and health in aging an observational study. Ann. Intern. Med. 2013, 159, 584-591. [CrossRef]

10. Walston, J.; Hadley, E.C.; Ferrucci, L.; Guralnik, J.M.; Newman, A.B.; Studenski, S.A.; Ershler, W.B.; Harris, T.; Fried, L.P. Research agenda for frailty in older adults: Toward a better understanding of physiology and aetiology: Summary from the American Geriatrics Society/National Institute on Aging Research Conference on Frailty in Older Adults. J. Am. Geriatr. Soc. 2006, 54, 991-1001. [CrossRef]

11. Eeles, E.M.; White, S.V.; O'Mahony, S.M.; Bayer, A.J.; Hubbard, R.E. The impact of frailty and delirium on mortality in older inpatients. Age Ageing 2012, 41, 412-416. [CrossRef]

12. Strandberg, T.E.; Pitkälä, K.H. Frailty in elderly people. Lancet 2007, 369, 1328-1329. [CrossRef]

13. Fried, L.P.; Tangen, C.M.; Walston, J.; Newman, A.B.; Hirsch, C.; Gottdiener, J.; Seeman, T.; Tracy, R.; Kop, W.J.; Burke, G.; et al. Frailty in older adults: Evidence for a phenotype. J. Gerontol. A Biol. Sci. Med. Sci. 2001, 56, M146-M157. [CrossRef]

14. Rockwood, K.; Song, X.; MacKnight, C.; Bergman, H.; Hogan, D.B.; McDowell, I.; Mitnitski, A. A global clinical measure of fitness and frailty in elderly people. CMAJ 2005, 173, 489-495. [CrossRef]

15. Clegg, A. Frailty in elderly people. Lancet 2013, 381, 752-762. [CrossRef]

16. Song, X.; Mitnitski, A.; Rockwood, K. Prevalence and 10-year outcomes of frailty in older adults in relation to deficit accumulation. J. Am. Geriatr. Soc. 2010, 58, 681-687. [CrossRef] [PubMed]

17. Fried, L.P.; Ferrucci, L.; Darer, J.; Williamson, J.D.; Anderson, G. Untangling the concepts of disability, frailty, and comorbidity: Implications for improved targeting and care. J. Gerontol. 2004, 59, 255-263. [CrossRef] [PubMed]

18. Fried, L.P.; Ferrucci, L.; Darer, J.; Williamson, J.D.; Anderson, G. Phenotype of frailty: Characterization in the women's health and aging studies. J. Gerontol. A Biol. Sci. Med. Sci. 2006, 61, 262-266.

19. Morley, J.E.; Haren, M.T.; Rolland, Y.; Kim, M.J. Frailty. Med. Clin. N. Am. 2006, 90, 837-847. [CrossRef] 
20. Flatt, T. A new definition of aging? Front. Genet. 2012, 3, 148. [CrossRef]

21. Giaimo, S.; d'Adda di Fagagna, F. Is cellular senescence an example of antagonistic pleiotropy? Aging Cell 2012, 11, 378-383. [CrossRef]

22. Sharpless, N.E. Loss of p16Ink4a with retention of p19Arf predisposes mice to tumorigenesis. Nature 2001, 413, 86-91. [CrossRef]

23. Sager, R. Senescence as a mode of tumor suppression. Environ. Health Perspect. 1991, 93, 59-62. [CrossRef]

24. Baker, D.J. Clearance of p16Ink4a-positive senescent cells delays ageing-associated disorders. Nature 2011, 479, 232-236. [CrossRef]

25. Baker, D.J. Opposing roles for p16Ink4a and p19Arf in senescence and ageing caused by BubR1 insufficiency. Nat. Cell Biol. 2008, 10, 825-836. [CrossRef] [PubMed]

26. Baker, D.J. BubR1 insufficiency causes early onset of aging-associated phenotypes and infertility in mice. Nat. Genet. 2004, 36, 744-749. [CrossRef] [PubMed]

27. Childs, B.G.; Durik, M.; Baker, D.J.; van Deursen, J.M. Cellular senescence in aging and age-related disease: From mechanisms to therapy. Nat. Med. 2015, 21, 1424-1435. [CrossRef]

28. Kaszubowska, L. Telomere shortening and ageing of the immune system. J. Physiol. Pharmacol. 2008, 59 (Suppl. S9), 169-186. [PubMed]

29. Titus, S. Impairment of BRCA1-related DNA double-strand break repair leads to ovarian aging in mice and humans. Sci. Transl. Med. 2013, 5, 172ra121. [CrossRef] [PubMed]

30. Brown, M.K.; Naidoo, N. The endoplasmic reticulum stress response in aging and age-related diseases. Front. Physiol. 2012, 3, 263. [CrossRef] [PubMed]

31. Shimizu, I. p53-induced adipose tissue inflammation is critically involved in the development of insulin resistance in heart failure. Cell Metab. 2012, 15, 51-64. [CrossRef]

32. Minamino, T. A crucial role for adipose tissue p53 in the regulation of insulin resistance. Nat. Med. 2009, 15, 1082-1087. [CrossRef]

33. Ryan, A.S. Insulin resistance with aging: Effects of diet and exercise. Sports Med. 2000, 30, 327-346. [CrossRef]

34. Walters, M.S. Smoking accelerates aging of the small airway epithelium. Respir. Res. 2014, 15, 94. [CrossRef]

35. Wilcox, G. Insulin and insulin resistance. Clin. Biochem. Rev. 2005, 26, 19-39. [PubMed]

36. $\mathrm{Xu}, \mathrm{H}$. Chronic inflammation in fat plays a crucial role in the development of obesity-related insulin resistance. J. Clin. Investig. 2003, 112, 1821-1830. [CrossRef] [PubMed]

37. Roden, M. Mechanism of free fatty acid-induced insulin resistance in humans. J. Clin. Investig. 1996, 97, 2859-2865. [CrossRef] [PubMed]

38. Guo, N. Short telomeres compromise beta-cell signaling and survival. PLoS ONE 2011, 6, e17858.

39. Yang, T.K. Davallialactone from mushroom reduced premature senescence and inflammation on glucose oxidative stress in human diploid fibroblast cells. J. Agric. Food Chem. 2013, 61, 7089-7095. [CrossRef]

40. Liu, J. Receptor for advanced glycation end-products promotes premature senescence of proximal tubular epithelial cells via activation of endoplasmic reticulum stress-dependent p21 signaling. Cell. Signal. 2014, 26, 110-121. [CrossRef]

41. Mortuza, R.; Chen, S.; Feng, B.; Sen, S.; Chakrabarti, S. High glucose induced alteration of SIRTs in endothelial cells causes rapid aging in a p300 and FOXO regulated pathway. PLoS ONE 2013, 8, e54514. [CrossRef]

42. Kim, Y.J. miR-486-5p induces replicative senescence of human adipose tissue-derived mesenchymal stem cells and its expression is controlled by high glucose. Stem. Cells Dev. 2012, 21, 1749-1760. [CrossRef]

43. Salpea, K.D.; Humphries, S.E. Telomere length in atherosclerosis and diabetes. Atherosclerosis 2010, 209, 35-38. [CrossRef]

44. Kawashima, S.; Yokoyama, M. Dysfunction of endothelial nitric oxide synthase and atherosclerosis. Arterioscler. Thromb. Vasc. Biol. 2004, 24, 998-1005. [CrossRef]

45. Barzilai, N.; Banerjee, S.; Hawkins, M.; Chen, W.; Rossetti, L. Caloric restriction reverses hepatic insulin resistance in aging rats by decreasing visceral fat. J. Clin. Investig. 1998, 101, 1353-1361. [CrossRef] [PubMed]

46. Fontana, L.; Partridge, L. Promoting health and longevity through diet: From model organisms to humans. Cell 2015, 161, 106-118. [CrossRef] [PubMed]

47. Salvestrini, V.; Sell, C.; Lorenzini, A. Obesity May Accelerate the Aging Process. Front. Endocrinol. 2019, 10, 266. [CrossRef] [PubMed]

48. Sen, P.; Shah, P.P.; Nativio, R.; Berger, S.L. Epigenetic Mechanisms of Longevity and Aging. Cell 2016, 166, 822-839. [CrossRef] [PubMed] 
49. Finkel, T. The metabolic regulation of aging. Nat. Med. 2015, 21, 1416-1423. [CrossRef] [PubMed]

50. Bertrand, H.A.; Lynd, F.T.; Masoro, E.J.; Yu, B.P. Changes in adipose mass and cellularity through the adult life of rats fed ad libitum or a life-prolonging restricted diet. J. Gerontol. 1980, 35, 827-835. [CrossRef]

51. Liao, C.Y.; Rikke, B.A.; Johnson, T.E.; Diaz, V.; Nelson, J.F. Genetic variation in the murine lifespan response to dietary restriction: From life extension to life shortening. Aging Cell 2010, 9, 92-95. [CrossRef]

52. Speakman, J.R.; Mitchell, S.E. Caloric restriction. Mol. Asp. Med. 2011, 32, 159-221. [CrossRef]

53. Liao, C.Y. Fat maintenance is a predictor of the murine lifespan response to dietary restriction. Aging Cell 2011, 10, 629-639. [CrossRef]

54. Vermeij, W.P. Restricted diet delays accelerated ageing and genomic stress in DNA-repair-deficient mice. Nature 2016, 537, 427-447. [CrossRef]

55. Huffman, K.M. Caloric restriction alters the metabolic response to a mixed-meal: Results from a randomized, controlled trial. PLoS ONE 2012, 7, e28190. [CrossRef] [PubMed]

56. Riera, C.E.; Dillin, A. Tipping the metabolic scales towards increased longevity in mammals. Nat. Cell Biol. 2015, 17, 196-203. [CrossRef] [PubMed]

57. Willette, A.A. Interleukin-8 and interleukin-10, brain volume and microstructure, and the influence of calorie restriction in old rhesus macaques. Age 2013, 35, 2215-2227. [CrossRef] [PubMed]

58. Youm, Y.H. The ketone metabolite $\beta$-hydroxybutyrate blocks NLRP3 inflammasome-mediated inflammatory disease. Nat. Med. 2015, 21, 263-269. [CrossRef]

59. Yang, H.; Youm, Y.H.; Dixit, V.D. Inhibition of thymic adipogenesis by caloric restriction is coupled with reduction in age-related thymic involution. J. Immunol. 2009, 183, 3040-3052. [CrossRef]

60. Masoro, E.J. Overview of caloric restriction and ageing. Mech. Ageing Dev. 2005, 126, 913-922. [CrossRef]

61. Dillin, A. Rates of behavior and aging specified by mitochondrial function during development. Science 2002, 298, 2398-2401. [CrossRef]

62. Lee, S.S. A systematic RNAi screen identifies a critical role for mitochondria in C. elegans longevity. Nat. Genet. 2003, 33, 40-48. [CrossRef]

63. Trifunovic, A. Premature ageing in mice expressing defective mitochondrial DNA polymerase. Nature 2004, 429, 417-423. [CrossRef]

64. Kujoth, G.C. Mitochondrial DNA mutations, oxidative stress, and apoptosis in mammalian aging. Science 2005, 309, 481-484. [CrossRef]

65. Rea, S.L.; Ventura, N.; Johnson, T.E. Relationship between mitochondrial electron transport chain dysfunction, development, and life extension in Caenorhabditis elegans. PLoS Biol. 2007, 5, e259. [CrossRef] [PubMed]

66. Harman, D. Aging: A theory based on free radical and radiation chemistry. J. Gerontol. 1956, 11, $298-300$. [CrossRef] [PubMed]

67. Barja, G. The mitochondrial free radical theory of aging. Prog. Mol. Biol. Transl. Sci. 2014, 127, 1-27. [PubMed]

68. Calabrese, E.J.; Bachmann, K.A.; Bailer, A.J.; Bolger, P.M.; Borak, J.; Cai, L.; Cedergreen, N.; Cherian, M.G.; Chiueh, C.C.; Clarkson, T.W.; et al. Biological stress response terminology: Integrating the concepts of adaptive response and preconditioning stress within a hormetic dose-response framework. Toxicol. Appl. Pharmacol. 2007, 222, 122-128. [CrossRef] [PubMed]

69. Yun, J.; Finkel, T. Mitohormesis. Cell Metab. 2014, 19, 757-766. [CrossRef]

70. Ristow, M. Unraveling the truth about antioxidants: Mitohormesis explains ROS-induced health benefits. Nat. Med. 2014, 20,709-711. [CrossRef]

71. Ristow, M.; Schmeisser, K. Mitohormesis: Promoting health and lifespan by increased levels of reactive oxygen species (ROS). Dose Response 2014, 12, 288-341. [CrossRef]

72. López-Lluch, G. Calorie restriction induces mitochondrial biogenesis and bioenergetic efficiency. Proc. Natl. Acad. Sci. USA 2006, 103, 1768-1773. [CrossRef]

73. Finley, L.W. Skeletal muscle transcriptional coactivator PGC-1 $\alpha$ mediates mitochondrial, but not metabolic, changes during calorie restriction. Proc. Natl. Acad. Sci. USA 2012, 109, 2931-2936. [CrossRef]

74. Gomes, A.P. Declining NAD+ induces a pseudohypoxic state disrupting nuclear-mitochondrial communication during aging. Cell 2013, 155, 1624-1638. [CrossRef]

75. Cuervo, A.M. Autophagy and aging: The importance of maintaining "clean" cells. Autophagy 2005, 1, 131-140. [CrossRef] [PubMed] 
76. Rana, A.; Rera, M.; Walker, D.W. Parkin overexpression during aging reduces proteotoxicity, alters mitochondrial dynamics, and extends lifespan. Proc. Natl. Acad. Sci. USA 2013, 110, 8638-8643. [CrossRef] [PubMed]

77. Bird, A. DNA methylation patterns and epigenetic memory. Genes Dev. 2002, 16, 6-21. [CrossRef] [PubMed]

78. Horvath, S. DNA methylation age of human tissues and cell types. Genome Biol. 2013, 14, 3156. [CrossRef]

79. Maegawa, S. Caloric restriction delays age-related methylation drift. Nat. Commun. 2017, 8, 539. [CrossRef]

80. Redman, L.M. Metabolic Slowing and Reduced Oxidative Damage with Sustained Caloric Restriction Support the Rate of Living and Oxidative Damage Theories of Aging. Cell Metab. 2018, 27, 1-11. [CrossRef]

81. Willett, W.C.; Sacks, F.; Trichopoulou, A.; Drescher, G.; Ferro-Luzzi, A.; Helsing, E.; Trichopoulos, D. Mediterranean diet pyramid: A cultural model for healthy eating. Am. J. Clin. Nutr. 1995, 61 (Suppl. S6), S1402-S1406. [CrossRef]

82. Fundación Dieta Mediterránea. 2010. Available online: https://dietamediterranea.com (accessed on 1 June 2019).

83. Keys, A.B. Seven Countries: A Multivariate Analysis of Death and Coronary Heart Disease; Harvard University Press: Cambridge, MA, USA, 1980; p. 381.

84. Trichopoulou, A. Adherence to a Mediterranean Diet and Survival in a Greek Population. N. Engl. J. Med. 2003, 348, 2599-2608. [CrossRef]

85. Trichopoulou, A. Diet and overall survival in the elderly. BMJ 1995, 311, 1457-1460. [CrossRef]

86. Estruch, R. Primary Prevention of Cardiovascular Disease with a Mediterranean Diet. N. Engl. J. Med. 2013, 368, 1279-1290. [CrossRef]

87. Estruch, R.; Ros, E.; Salas-Salvadó, J.; Covas, M.I.; Corella, D.; Arós, F.; Gómez-Gracia, E.; Ruiz-Gutiérrez, V.; Fiol, M.; Lapetra, J.; et al. Primary Prevention of Cardiovascular Disease with a Mediterranean Diet Supplemented with Extra-Virgin Olive Oil or Nuts. N. Engl. J. Med. 2018, 378, e34. [CrossRef]

88. Sofi, F. Adherence to Mediterranean diet and health status: Meta-analysis. BMJ 2008, 337, a1344. [CrossRef] [PubMed]

89. Sofi, F. Accruing evidence on benefits of adherence to the Mediterranean diet on health: An updated systematic review and meta-analysis. Am. J. Clin. Nutr. 2010, 92, 1189-1196. [CrossRef] [PubMed]

90. Voelker, R. The Mediterranean Diet's Fight against Frailty. JAMA 2018, 319, 1971-1972. [CrossRef] [PubMed]

91. Bach-Faig, A. Mediterranean diet pyramid today. Science and cultural updates. Public Health Nutr. 2011, 14, 2274-2284. [CrossRef]

92. Kromhout, D. Comparative ecologic relationships of saturated fat, sucrose, food groups, and a Mediterranean food pattern score to 50-year coronary heart disease mortality rates among 16 cohorts of the Seven Countries Study. Eur. J. Clin. Nutr. 2018, 72, 1103-1110. [CrossRef]

93. GISSI-Prevenzione Investigators (Gruppo Italiano per lo Studio della Sopravvivenza nell'Infarto miocardico). Dietary supplementation with n-3 polyunsaturated fatty acids and vitamin $\mathrm{E}$ after myocardial infarction: Results of the GISSI-Prevenzione trial. Lancet 1999, 354, 447-455. [CrossRef]

94. Yokoyama, M. Japan EPA lipid intervention study (JELIS) Investigators. Effects of eicosapentaenoic acid on major coronary events in hypercholesterolaemic patients (JELIS): A randomised open-label, blinded endpoint analysis. Lancet 2007, 369, 1090-1098. [CrossRef]

95. Kromhout, D. Alpha Omega Trial Group. N-3 fatty acids and cardiovascular events aftermyocardial infarction. N. Engl. J. Med. 2010, 363, 2015-2026. [CrossRef]

96. Einvik, G. A randomized clinical trial on N-3 polyunsaturated fatty acids supplementation and all-cause mortality in elderly men at high cardiovascular risk. Eur. J. Cardiovasc. Prev. Rehabil. 2010, 17, 588-592. [CrossRef]

97. Bosch, J. ORIGIN Trial Investigators. N-3 fatty acids and cardiovascular outcomes in patients with dysglycemia. N. Engl. J. Med. 2012, 367, 309-318. [PubMed]

98. Rauch, B. OMEGA Study Group. OMEGA, a randomized, placebo-controlled trial to test the effect of highly purified omega-3 fatty acids on top of modern guideline-adjusted therapy after myocardial infarction. Circulation 2010, 122, 2152-2159. [CrossRef] [PubMed]

99. Galan, P. OM3 Collaborative Group. Effects of B vitamins and omega 3 fatty acids on cardiovascular diseases: A randomised placebo controlled trial. BMJ 2010, 341, c6273. [CrossRef] [PubMed] 
100. Bonds, D.E. Writing Group for the AREDS2 Research Group. Effect of long-chain $\omega$-3 fatty acids and lutein + zeaxanthin supplements on cardiovascular outcomes: Results of the Age-Related Eye Disease Study 2 (AREDS2) randomized clinical trial. JAMA Intern. Med. 2014, 174, 763-771. [PubMed]

101. Deepak, L.; Bhatt, D.L. Cardiovascular Risk Reduction with Icosapent Ethyl for Hypertriglyceridemia. $N$. Engl. J. Med. 2019, 380, 11-22.

102. Bucher, H.C. N-3 polyunsaturated fatty acids in coronary heart disease: A meta-analysis of randomized controlled trials. Am. J. Med. 2002, 112, 298-304. [CrossRef]

103. Rizos, E.C. Association between omega-3 fatty acid supplementation and risk of major cardiovascular disease events: A systematic review and meta-analysis. JAMA 2012, 308, 1024-1033. [CrossRef]

104. Kwak, S.M. Korean Meta-analysis Study Group. Efficacy of omega-3 fatty acid supplements (eicosapentaenoic acid and docosahexaenoic acid) in the secondary prevention of cardiovascular disease: Ameta-analysis of randomized, double-blind, placebo-controlled trials. Arch. Intern. Med. 2012, 172, 686-694.

105. Agency for Heathcare Research and Quality. Omega-3 Fatty Acids and Cardiovascular Disease: An Updated Systemative Review. Evidence Report/Technology Assessment No. 223. Available online: https://effectivehealthcare.ahrq.gov/sites/default/files/related_files/fatty-acidscardiovascular-disease_executive.pdf (accessed on 3 June 2019).

106. Zhang, Y. Association of fish and long-chain omega-3 fatty acids intakes with total and cause-specific mortality: Prospective analysis of 421309 individuals. J. Intern. Med. 2018, 284, 399-417. [CrossRef]

107. Siscovick, D.S. Omega-3 Polyunsaturated Fatty Acid (Fish Oil) Supplementation and the Prevention of Clinical Cardiovascular Disease: A Science Advisory from the American Heart Association. Circulation 2017, 135, e867-e884. [CrossRef]

108. Tavazzi, L. Gissi-HF Investigators. Effect of n-3 polyunsaturated fatty acids in patients with chronic heart failure (the GISSI-HF trial): A randomised, double-blind, placebo-controlled trial. Lancet 2008, 372, 1223-1230. [CrossRef] [PubMed]

109. Qi, W. The $\omega-3$ fatty acid $\alpha$-linolenic acid extends Caenorhabditis elegans lifespan via NHR- $49 / \mathrm{PPAR} \alpha$ and oxidation to oxylipins. Aging Cell 2017, 16, 1125-1135. [CrossRef] [PubMed]

110. Mathers, J.C. Nutrition and ageing: Knowledge, gaps and research priorities. Proc. Nutr. Soc. 2013, 72, 246-250. [CrossRef] [PubMed]

111. Bishop, N.A.; Lu, T.; Yankner, B.A. Neural mechanisms of ageing and cognitive decline. Nature 2010, 464, 529-535. [CrossRef] [PubMed]

112. Huffman, D.M. Energetic interventions for healthspan and resiliency with aging. Exp. Gerontol. 2016, 86, 73-83. [CrossRef]

113. Arvanitakis, Z.; Shah, R.C.; Bennett, D.A. Diagnosis and management of dementia: A review. JAMA 2019, 322, 1589-1599. [CrossRef]

114. Lafortune, L. Behavioural Risk Factors in Mid-Life Associated with Successful Ageing, Disability, Dementia and Frailty in Later Life: A Rapid Systematic Review. PLoS ONE 2016, 11, e0144405. [CrossRef]

115. Trichopoulou, A. Modified Mediterranean diet and survival: EPIC-elderly prospective cohort study. BMJ 2005, 330, 991. [CrossRef]

116. Shi, Z. Food Habits, Lifestyle Factors and Mortality among Oldest Old Chinese: The Chinese Longitudinal Healthy Longevity Survey (CLHLS). Nutrients 2015, 7, 7562-7579. [CrossRef]

117. Carruba, G. Nutrition, aging and cancer: Lessons from dietary intervention studies. Immun. Ageing 2016, 13, 13. [CrossRef]

118. Serra-Majem, L.; Roman, B.; Estruch, R. Scientific evidence of interventions using the Mediterranean diet: A systematic review. Nutr. Rev. 2006, 64, 27-47. [CrossRef]

119. Rees, K. "Mediterranean" dietary pattern for the primary prevention of cardiovascular disease. Cochrane Database Syst. Rev. 2013, 8, CD009825. [CrossRef] [PubMed]

120. Sleiman, D.; Al-Badri, M.R.; Azar, S.T. Effect of Mediterranean diet in diabetes control and cardiovascular risk modification: A systematic review. Front. Public Health 2015, 3, 69. [CrossRef] [PubMed]

121. Bonaccio, M.; Cerletti, C.; Iacoviello, L.; de Gaetano, G. Mediterranean diet and low-grade subclinical inflammation: The moli-sani study. Endocr. Metab. Immune Disord. Drug Targets 2015, 15, 18-24. [CrossRef] [PubMed]

122. Di Renzo, L. Changes in LDL oxidative status and oxidative and inflammatory gene expression after red wine intake in healthy people: A randomized trial. Mediat. Inflamm. 2015, 2015, 317348. [CrossRef] [PubMed] 
123. Milte, C.M.; McNaughton, S.A. Dietary patterns and successful ageing: A systematic review. Eur. J. Nutr. 2016, 55, 423-450. [CrossRef]

124. Parletta, N.; Milte, C.M.; Meyer, B.J. Nutritional modulation of cognitive function and mental health. J. Nutr. Biochem. 2013, 24, 725-743. [CrossRef]

125. Smaga, I. Oxidative stress as an etiological factor and a potential treatment target of psychiatric disorders. Part 2. Depression, anxiety, schizophrenia and autism. Pharmacol. Rep. 2015, 67, 569-580. [CrossRef]

126. Ticinesi, A. Nutrition and Inflammation in Older Individuals: Focus on Vitamin, D.; n-3 Polyunsaturated Fatty Acids and Whey Proteins. Nutrients 2016, 8, 186. [CrossRef]

127. Giunta, B. Inflammaging as a prodrome to Alzheimer's disease. J. Neuroinflamm. 2008, 5, 51. [CrossRef]

128. Stepanova, M. Age-independent rise of inflammatory scores may contribute to accelerated aging in multimorbidity. Oncotarget 2015, 6, 1414-1421. [CrossRef] [PubMed]

129. Ostan, R. Inflammaging and cancer: A challenge for the Mediterranean diet. Nutrients 2015, 7, $2589-2621$. [CrossRef] [PubMed]

130. Brown, P.J. Inflammation, depression, and slow gait: A high mortality phenotype in later life. J. Gerontol. A Biol. Sci. Med. Sci. 2016, 71, 221-227. [CrossRef] [PubMed]

131. Giovannini, S. Interleukin-6, C-reactive protein, and tumor necrosis factor-alpha as predictors of mortality in frail, community-living elderly individuals. J. Am. Geriatr. Soc. 2011, 59, 1679-1685. [CrossRef]

132. Cederholm, T. The role of malnutrition in older persons with mobility limitations. Curr. Pharm. Des. 2014, 20, 3173-3177. [CrossRef]

133. Jensen, G.L. Malnutrition and inflammation-“Burning down the house”: Inflammation as an adaptive physiologic response versus self-destruction? J. Parenter Enter. Nutr. 2015, 39, 56-62. [CrossRef]

134. Batt, J.; Dos Santos, C.C.; Herridge, M.S. Muscle injury during critical illness. J. Am. Med. Assoc. 2013, 310, 1569-1570. [CrossRef]

135. Nouvenne, A. The prognostic value of high-sensitivity C-reactive protein and prealbumin for short-term mortality in acutely hospitalized multimorbid elderly patients: A prospective cohort study. J. Nutr. Health Aging 2016, 20, 462-468. [CrossRef]

136. Haran, P.H.; Rivas, D.A.; Fielding, R.A. Role and potential mechanisms of anabolic resistance in sarcopenia. J. Cachexia Sarcopenia Muscle 2012, 3, 157-162. [CrossRef]

137. Kelaiditi, E. Measurements of skeletal muscle mass and power are positively related to a Mediterranean dietary pattern in women. Osteoporos. Int. 2016, 27, 3251-3260. [CrossRef]

138. Huang, R.Y. The Association between Total Protein and Vegetable Protein Intake and Low Muscle Mass among the Community-Dwelling Elderly Population in Northern Taiwan. Nutrients 2016, 8, 373. [CrossRef] [PubMed]

139. Ter Borg, S. Differences in Nutrient Intake and Biochemical Nutrient Status Between Sarcopenic and Nonsarcopenic Older Adults-Results From the Maastricht Sarcopenia Study. J. Am. Med. Dir. Assoc. 2016, 17, 393-401. [CrossRef] [PubMed]

140. Verlaan, S. Nutritional status, body composition, and quality of life in community-dwelling sarcopenic and non-sarcopenic older adults: A case-control study. Clin. Nutr. 2017, 36, 267-274. [CrossRef] [PubMed]

141. Barrea, L. Association between Mediterranean diet and hand grip strength in older adult women. Clin. Nutr. 2019, 38, 721-729. [CrossRef] [PubMed]

142. Granic, A.; Sayer, A.A.; Robinson, S.M. Dietary Patterns, Skeletal Muscle Health, and Sarcopenia in Older Adults. Nutrients 2019, 11, 745. [CrossRef] [PubMed]

143. Fiatarone, M.A. Exercise training and nutritional supplementation for physical frailty in very elderly people. N. Engl. J. Med. 1994, 330, 1769-1775. [CrossRef]

144. Bonnefoy, M. Frailty and nutrition: Searching for evidence. J. Nutr. Health Aging 2015, 19, 250-257. [CrossRef]

145. Kiefte-de Jong, J.C.; Mathers, J.C.; Franco, O.H. Nutrition and healthy ageing: The key ingredients. Proc. Nutr. Soc. 2014, 73, 249-259. [CrossRef]

146. Milaneschi, Y.; Bandinelli, S.; Corsi, A.M.; Lauretani, F.; Paolisso, G.; Dominguez, L.J.; Semba, R.D.; Tanaka, T.; Abbatecola, A.M.; Talegawkar, S.A.; et al. Mediterranean diet and mobility decline in older persons. Exp. Gerontol. 2011, 46, 303-308. [CrossRef]

147. Bollwein, J.; Diekmann, R.; Kaiser, M.J.; Bauer, J.M.; Uter, W.; Sieber, C.C.; Volkert, D. Dietary quality is related to frailty in community-dwelling older adults. J. Gerontol. A Biol. Sci. Med. Sci. 2013, 68, 483-489. [CrossRef] 
148. Rodacki, C.L.N. Fish-oil supplementation enhances the effects of strength training in elderly women. Am. J. Clin. Nutr. 2012, 95, 428-436. [CrossRef] [PubMed]

149. Hutchins-Wiese, H.L. The impact of supplemental n-3 long chain polyunsaturated fatty acids and dietary antioxidants on physical performance in postmenopausal women. J. Nutr. Health Aging 2013, 17, 76-80. [CrossRef] [PubMed]

150. Takayama, M. Association of marine-origin n-3 polyunsaturated fatty acids consumption and functional mobility in the community-dwelling oldest old. J. Nutr. Health Aging 2013, 17, 82-89. [CrossRef] [PubMed]

151. Biolo, G. Short-term bed rest impairs amino acid-induced protein anabolism in humans. J. Physiol. 2004, 558, 381-388. [CrossRef]

152. Volpi, E.; Mittendorfer, B.; Rasmussen, B.B.; Wolfe, R.R. The response of muscle protein anabolism to combined hyperaminoacidemia and glucose-induced hyperinsulinemia is impaired in the elderly. J. Clin. Endocrinol. Metab. 2000, 85, 4481-4490. [CrossRef]

153. Magne, H.; Savary-Auzeloux, I.; Rémond, D.; Dardevet, D. Nutritional strategies to counteract muscle atrophy caused by disuse and to improve recovery. Nutr. Res. Rev. 2013, 26, 149-165. [CrossRef]

154. Tieland, M.; Borgonjen-Van den Berg, K.J.; van Loon, L.J.C.; de Groot, L.C. Dietary protein intake in community-dwelling, frail, and institutionalized elderly people: Scope for improvement. Eur. J. Nutr. 2012, 51, 173-179. [CrossRef]

155. Talegawkar, S.A.; Bandinelli, S.; Bandeen-Roche, K.; Chen, P.; Milaneschi, Y.; Tanaka, T.; Semba, R.D.; Guralnik, J.M.; Ferrucci, L. A Higher Adherence to a Mediterranean-Style Diet Is Inversely Associated with the Development of Frailty in Community-Dwelling Elderly Men and Women. J. Nutr. 2012, 142, 2161-2166. [CrossRef]

156. León-Muñoz, L.M.; García-Esquinas, E.; López-García, E.; Banegas, J.R.; Rodríguez-Artalejo, F. Major dietary patterns and risk of frailty in older adults: A prospective cohort study. BMC Med. 2015, 13, 11. [CrossRef]

157. Chan, R.; Leung, J.; Woo, J. Dietary Patterns and Risk of Frailty in Chinese Community-Dwelling Older People in Hong Kong: A Prospective Cohort Study. Nutrients 2015, 7, 7070-7084. [CrossRef]

158. Woo, J.; Leung, S.S.F.; Ho, S.C.; Lam, T.H.; Janus, E.D. A food frequency questionnaire for use in the Chinese population in Hong Kong: Description and examination of validity. Nutr. Res. 1997, 17, 1633-1641. [CrossRef]

159. Chan, R.; Chan, D.; Woo, J. Associations between dietary patterns and demographics, lifestyle, anthropometry and blood pressure in Chinese community-dwelling older men and women. J. Nutr. Sci. 2012, 1, e20. [CrossRef] [PubMed]

160. Kim, S.; Haines, P.S.; Siega-Riz, A.M.; Popkin, B.M. The Diet Quality Index-International (DQI-I) provides an effective tool for cross-national comparison of diet quality as illustrated by China and the United States. $J$. Nutr. 2003, 133, 3476-3484. [CrossRef] [PubMed]

161. Woo, J.; Cheung, B.; Ho, S.; Sham, A.; Lam, T.H. Influence of dietary pattern on the development of overweight in a Chinese population. Eur. J. Clin. Nutr. 2008, 62, 480-487. [CrossRef] [PubMed]

162. Chan, R.; Chan, D.; Woo, J. The association of a priori and a posterior dietary pattern with the risk of incident stroke in Chinese older people in Hong Kong. J. Nutr. Health Aging 2013, 17, 866-874. [CrossRef]

163. Rahi, B.; Ajana, S.; Tabue-Teguo, M.; Dartigues, J.F.; Peres, K.; Feart, C. High adherence to a Mediterranean diet and lower risk of frailty among French older adults community-dwellers: Results from the Three-City-Bordeaux Study. Clin. Nutr. 2017, 37, 1293-1298. [CrossRef]

164. Antoniak, M.; Pugliatti, M.; Hubbard, R.; Britton, J.; Sotgiu, S.; Sadovnick, A.D.; Yee, I.M.; Cumsille, M.A.; Bevilacqua, J.A.; Burdett, S.; et al. The Three City Study Group. Vascular factors and risk of dementia: Design of the Three-City Study and baseline characteristics of the study population. Neuroepidemiology 2003, 22, 316-325.

165. Veronese, N.; Stubbs, B.; Noale, M.; Solmi, M.; Rizzoli, R.; Vaona, A.; Demurtas, J.; Crepaldi, G.; Maggi, S. Adherence to a Mediterranean diet is associated with lower incidence of frailty: A longitudinal cohort study. Clin. Nutr. 2017, 37, 1492-1497. [CrossRef]

166. Felson, D.T.; Nevitt, M.C. Epidemiologic studies for osteoarthritis: New versus conventional study design approaches. Rheum. Dis. Clin. N. Am. 2004, 30, 783-797. [CrossRef]

167. The Osteoarthritis Initiative-A Multi-Center Observational Study of Men and Women. Available online: http://www.oai.ucsf.edu (accessed on 4 June 2019). 
168. Block, G.; Hartman, A.M.; Naughton, D. A reduced dietary questionnaire: Development and validation. Epidemiology 1990, 1, 58-64. [CrossRef]

169. Panagiotakos, D.B.; Pitsavos, C.; Stefanadis, C. Dietary patterns: A Mediterranean diet score and its relation to clinical and biological markers of cardiovascular disease risk. Nutr. Metab. Cardiovasc. Dis. 2006, 16, 559-568. [CrossRef] [PubMed]

170. Yannakoulia, M.; Ntanasi, E.; Anastasiou, C.A.; Scarmeas, N. Frailty and nutrition: From epidemiological and clinical evidence to potential mechanisms. Metabolism 2017, 68, 64-76. [CrossRef] [PubMed]

171. Burd, N.A.; Gorissen, S.H.; van Loon, L.J. Anabolic resistance of muscle protein synthesis with aging. Exerc. Sport Sci. Rev. 2013, 41, 169-173. [CrossRef] [PubMed]

172. Andriollo-Sanchez, M. Age-related oxidative stress and antioxidant parameters in middle-aged and older European subjects: The ZENITH study. Eur. J. Clin. Nutr. 2005, 59 (Suppl. S2), S58-S62. [CrossRef] [PubMed]

173. Junqueira, V.B. Aging and oxidative stress. Mol. Asp. Med. 2004, 25, 5-16. [CrossRef] [PubMed]

174. Zujko, M.E.; Witkowska, A.M.; Waskiewicz, A.; Mironczuk-Chodakowska, I. Dietary antioxidant and flavonoid intakes are reduced in the elderly. Oxid. Med. Cell. Longev. 2015, 2015, 843173. [CrossRef]

175. Manolagas, S.C. From estrogen-centric to aging and oxidative stress: A revised perspective of the pathogenesis of osteoporosis. Endocr. Rev. 2010, 31, 266-300. [CrossRef]

176. Meng, S.J.; Oxidative, Y.L.J. Stress, molecular inflammation and sarcopenia. Int. J. Mol. Sci. 2010, 11, 1509-1526. [CrossRef]

(C) 2019 by the authors. Licensee MDPI, Basel, Switzerland. This article is an open access article distributed under the terms and conditions of the Creative Commons Attribution (CC BY) license (http://creativecommons.org/licenses/by/4.0/). 